UNIVERSIDADE FEDERAL DE JUIZ DE FORA INSTITUTO DE CIÊNCIAS BIOLÓGICAS MESTRADO PROFISSIONAL EM ENSINO DE BIOLOGIA EM REDE NACIONAL PROFBIO

Roberto Cézar Tavela

Plantas Medicinais na Aprendizagem de Botânica do Ensino Médio 


\section{Roberto Cézar Tavela}

Plantas Medicinais na Aprendizagem de Botânica do Ensino Médio

Trabalho de Conclusão de Mestrado - TCM apresentado ao Mestrado Profissional em Ensino de Biologia em Rede Nacional PROFBIO, do Instituto de Ciências Biológicas da Universidade Federal de Juiz de Fora, como requisito para a obtenção do título Mestre em Ensino de Biologia. Área de concentração: Ensino de Biologia

Orientadora: Dra. Luciana Moreira Chedier

Coorientador: Dr. Bruno Esteves Conde

Juiz de Fora 
Imprimir na parte inferior, no verso da folha de rosto, a ficha disponível em: http://www.ufif.br/biblioteca/servicos/usando-a-ficha-catalografica/ 


\section{Roberto Cézar Tavela}

\section{Plantas Medicinais na Aprendizagem de Botânica do Ensino Médio}

Trabalho de Conclusão de Mestrado - TCM apresentado ao Mestrado Profissional em Ensino de Biologia em Rede Nacional PROFBIO, do Instituto de Ciências Biológicas da Universidade Federal de Juiz de Fora, como requisito para a obtenção do título Mestre em Ensino de Biologia. Área de concentração: Ensino de Biologia

Aprovado em 31 de maio de 2021

BANCA EXAMINADORA

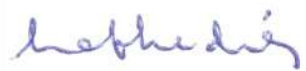

Dra. Luciana Moreira Chedier - Orientadora

Universidade Federal de Juiz de Fora

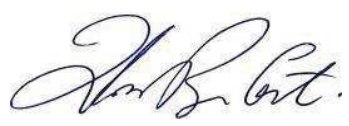

Dra. Viviana Borges Corte

Universidade Federal do Espírito Santo

Alomertrec

Dr. Aripuanã Sakurada Aranha Watanabe

Universidade Federal de Juiz de Fora 
Dedico essa dissertação a minha esposa Letícia pela paciência, apoio, incentivo e companheirismo, durante todo o curso de mestrado. 


\section{AGRADECIMENTOS}

Agradeço a Deus, aos meus pais e familiares que me apoiaram a todo momento com incontáveis preces.

A minha orientadora, professora Dra. Luciana Moreira Chedier, ao meu coorientador, Dr. Bruno Esteves Conde, e aos professores Dr. Aripuanã Sakurada Aranha Watanabe, Dra. Viviana Borges Corte, Dr. Marcelo de Oliveira Santos e Dra. Emília Ordones Lemos Saleh.

Aos companheiros de luta e queridos amigos que fiz no PROFBIO.

Em especial a minha esposa Letícia que foi meu alicerce e minha inspiração para seguir sempre em frente. Sempre me apoiando e me instruindo com muito amor, carinho e paciência.

Aos professores de Ensino Médio que optaram por participar desta pesquisa.

Ao Colégio Estadual Almirante Rodrigues Silva por fornecer os elementos essenciais para o desenvolvimento deste trabalho.

A Coordenação de Aperfeiçoamento de Pessoal de Nível Superior - Brasil (CAPES) Código de Financiamento 001, pelo apoio na realização do presente trabalho.

E a todas as pessoas que estiveram presentes em algum momento neste processo. 
Relato do Mestrando

\begin{tabular}{|l|}
\hline Instituição: UFJF/JF \\
\hline Mestrando: ROBERTO CÉZAR TAVELA \\
\hline Título do TCM: PLANTAS MEDICINAIS NA APRENDIZAGEM DE BOTÂNICA DO ENSINO \\
MÉDIO \\
\hline Data da defesa: 31/05/2021 \\
O programa de mestrado PROFBIO tem o objetivo de levar melhoria de ensino a instituições de ensino \\
básico, transformando um professor de ensino médio em um mestre no ensino de biologia com foco \\
em novas metodologias de ensino. Dessa forma, o profissional passa por uma capacitação que visa a \\
formação de jovens, que constroem seu próprio conhecimento e que são estimulados a desenvolver o \\
pensamento crítico. \\
O Programa de Mestrado Profissional em Ensino de Biologia me proporcionou dentre muitas \\
contribuições, a oportunidade de atualizar, ampliar e adquirir novos conhecimentos acerca de todas as \\
áreas da biologia. O time de professores é muito bem preparado e empenhado em permitir que o fluxo \\
de informações ocorra em todas as direções, formando, assim, um verdadeiro "rio" de conhecimento. \\
Quando busquei pelo mestrado, me sentia obsoleto e sem entusiasmo. O PROFBIO trouxe exatamente \\
o que eu precisava para me sentir renovado e orgulhoso de ser professor, podendo ajudar outras \\
pessoas a construírem seus conhecimentos e, também, podendo participar da formação de cidadãos de \\
bons hábitos e valores.
\end{tabular}


"Ensinar é um exercício de imortalidade. De alguma forma continuamos a viver naqueles cujos olhos aprenderam a ver o mundo pela magia da nossa palavra. O professor, assim, não morre jamais.” 


\section{RESUMO}

A Botânica tem sido considerada um componente árido, entediante e desanimador do currículo escolar pelos estudantes e pelas pessoas que já a estudaram. Aparentemente, o aluno não é capaz de perceber a presença das plantas em meio aos demais seres vivos, caracterizando o conceito de cegueira botânica. Estes seres exerceram e exercem um papel extremamente importante no que diz respeito à vida, à sociedade e ao planeta, tornando-se um assunto importantíssimo a ser aprendido. De acordo com a literatura acadêmica, a abordagem por meios não tradicionais de ensino resulta em uma aprendizagem mais significativa. Este dado motivou este trabalho, cuja proposta foi criar uma sequência didática que permitisse ao professor ser mais orientador e aos estudantes serem mais protagonistas do próprio conhecimento; para isso foram utilizados um questionário semiestruturado, que avalia o conhecimento prévio dos discentes, uma aula dialogada sobre as plantas (suas funções e usos pela sociedade), buscas e leitura de artigos científicos sobre as espécies selecionadas, a criação de um ambiente para cultivar as plantas, a produção de lâminas histológicas e, a partir destas, a criação de modelos de tecidos vegetais com massa de modelar. Apesar de muitas escolas não apresentarem espaço adequado e equipamentos, as atividades contidas nesta sequência didática podem ser moldadas para atender a todas as realidades, atingindo uma maior aprendizagem. Para avaliar esse trabalho foi elaborado um questionário semiestruturado e enviado por e-mail a professores de Ensino Médio, os quais apresentaram grande aceitação no que diz respeito à aplicação da sequência didática, à sua utilidade e ao seu incentivo ao protagonismo do estudante, revelando ser uma ótima opção de intervenção. De acordo com os resultados, este trabalho contribui para a melhoria da educação, para ajudar os professores em suas aulas, para a mudança de visão sobre os vegetais, além de ser uma referência para elaborações de novos trabalhos em outras escolas ou ambientes, levando à disseminação de mais conhecimento acerca da botânica e do próprio modelo de intervenção.

Palavras-chave: Atividades em botânica, cegueira botânica, ensino de botânica, ensino investigativo, ensino médio. 


\begin{abstract}
The Botany has been considered an arid field, and discouraging component of the school curriculum by students and people who have already studied it. Apparently, the student can't perceive the presence of plants among other living beings, which notices the concept of botanical blindness. These, propagate and still play an extremely important role in relation to life, society and the planet itself, making it a very important subject to be learned. According to the academic literature, a non-traditional teaching approach leads to a more meaningful learning process, applicable then in the objective of this work, which was to create a didactic sequence in order to allow the teacher to be more of an advisor while the students could be more protagonists of their own knowledge, using a semi-structured questionnaire that assesses students' previous knowledge; a lecture on plants and their functions and use by society; research and reading of scientific articles on selected species; creating an environment for growing plants; production of histological slides and, from these slides, a creation of models of plant tissues with modeling clay. Even though many schools do not have adequate areas and equipment, the activities of this didactic sequence can be modeled in order to meet all realities and achieve more learning. To evaluate this work, a semi-structured questionnaire was formulated and sent by e-mail to high school teachers, which must be widely accepted in the application of the didactic sequence, in its use and in its impulse to the student's role, proving to be a great option intervention. According to the results, this work contributes to Education, for teachers, for the change of vision about vegetables, besides being a reference for future elaborations in other schools or other environments, leading to the dissemination of more knowledge about botany and the intervention model itself.
\end{abstract}

Key-words: Botanical activities, Botanical Blindness, Botany Teaching, Investigative Teaching, High School. 


\section{LISTA DE ILUSTRAÇÕES}

Figura 1 Plectranthus barbatus Andrews. Hábito dos indivíduos estudados ...................... 16

Figura 2 Esqueletos básicos de diterpenos encontrados em Plectranthus sp..........................17

Figura 3 Plectranthus scutellarioides (L.) R. Br. Hábito dos indivíduos estudados.......... 18

Figura 4 Representação percentual do aparecimento das dificuldades de ensino de botânica categorizadas. 20

Figura 5 Mapa de localização do Município de Valença, Estado do Rio de Janeiro onde se localiza o Colégio Estadual Almirante Rodrigues Silva, cenário de desenvolvimento da intervenção "Plantas Medicinais na Aprendizagem de Botânica do Ensino Médio"...... .22

Figura 6 Exemplos das plantas selecionadas para a prática do trabalho "Plantas Medicinais na Aprendizagem de Botânica do Ensino Médio". A: Plectranthus barbatus Andrews boldo. B: Plectranthus scutellarioides (L.) R. Br - tapete 25

Figura 7 Representação da montagem das jardineiras contendo brita (A) para cobrir o fundo do vaso, areia (B) preenchendo os espaços entre as britas e finalizando com terra preta (C) e a camada mais superficial de terra vegetal (D) para inserção dos vegetais..... 26

Figura 8 Representação do questionário semiestruturado a ser respondido pelos professores de Ensino Médio vinculados ao

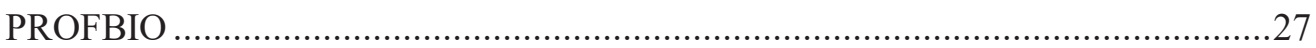

Figura 9 Representação quantitativa da sequência didática quanto ao tema, objetivo, conteúdo, tempo de aplicação e avaliação 29

Figura 10 Representação quantitativa sobre a sequência didática a ser aplicada em sala de aula

Figura 11 Representação quantitativa dos participantes que usam procedimentos práticos em suas aulas 30

Figura 12 Representação qualitativa dos motivos que levam os professores participantes da pesquisa a não fazerem procedimentos práticos 31

Figura 13 Representação qualitativa da experiência dos participantes da pesquisa que usam procedimentos práticos

Figura 14 Representação quantitativa da possibilidade de reprodução da metodologia usada neste trabalho

Figura 15 Representação quantitativa sobre a capacidade do cultivo das plantas e da confecção de lâminas histológicas incentivarem os estudantes a serem 
protagonistas .

33

Figura 16 Representação quantitativa dos professores partícipes sobre a utilidade da sequência didática construída... 


\section{LISTA DE QUADROS}

Quadro 1 - Questões utilizadas na aula dialogada para envolver e instigar os estudantes a terem uma participação ativa ........................................................................ 19

Quadro 2 - Categorização das dificuldades encontradas na revisão bibliográfica sobre o ensino de Botânica. 
INTRODUÇÃO

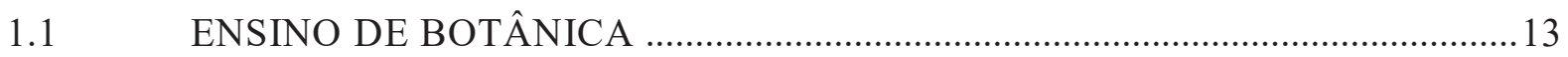

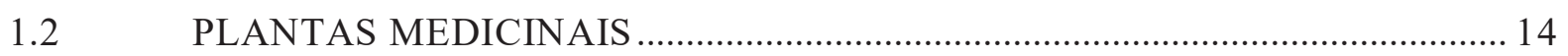

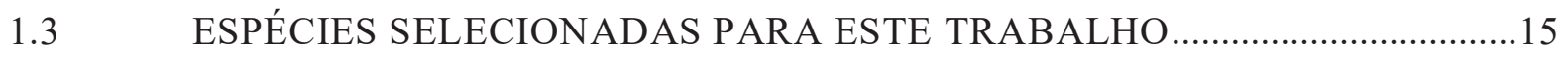

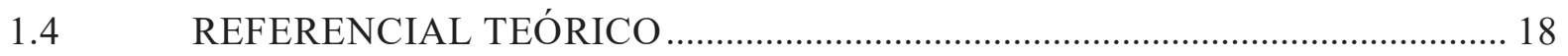

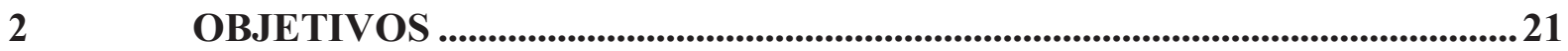

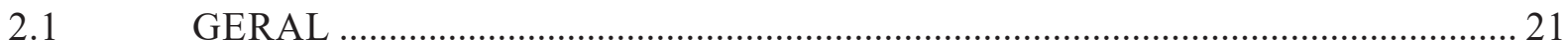

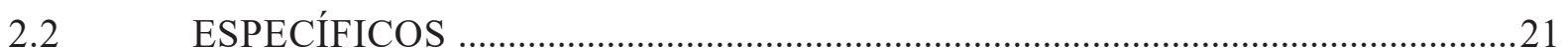

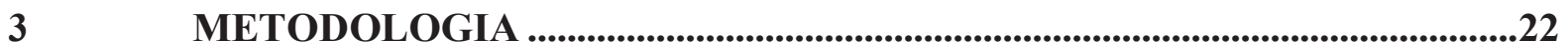

3.1 AUTORIZAÇÃO DE COMITÊ DE ÉTICA ….....................................................22

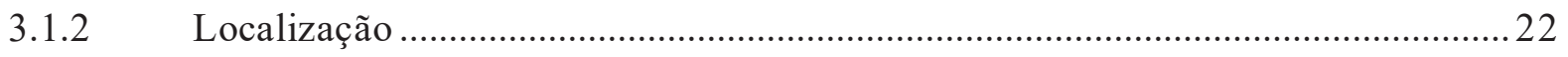

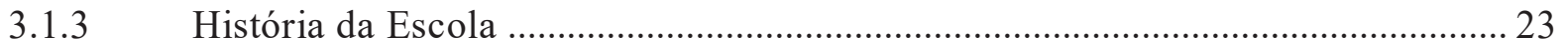

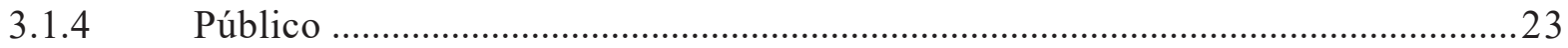

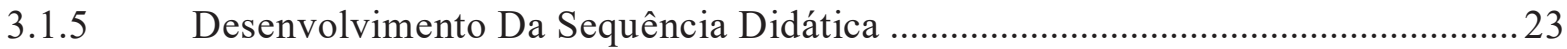

COLETA DE DADOS

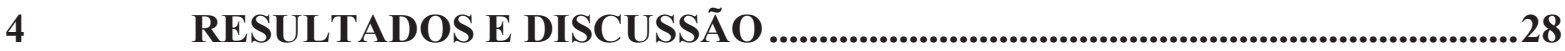

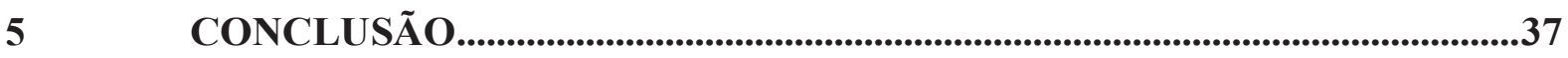

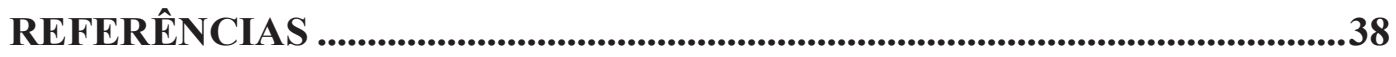

APÊNDICE A - Questionário para estudantes ......................................................4 47

APÊNDICE B - Questionário para professores ................................................49

ANEXO A - Produto ...........................................................................................

ANEXO B - Parecer do Comitê de Ética...............................................................65 



\section{INTRODUÇÃO}

A Botânica tem sido considerada um componente árido, entediante e desanimador do currículo escolar pelos estudantes e pelas pessoas que já a estudaram (SILVA et al., 2019). Aparentemente, o aluno não é capaz de perceber a presença das plantas em meio aos demais seres vivos (NEVES et al., 2019). Mesmo fora das escolas, os vegetais são reconhecidos como meros figurantes de um pano de fundo de tonalidade verde, caracterizando o que Wandersee e Schussler (2002) denominaram "cegueira botânica". Ainda, de acordo com estes pesquisadores, a explicação para o fato de as pessoas ignorarem as plantas está na neurofisiologia, que é o estudo das funções e do funcionamento do sistema nervoso dos seres vivos, de acordo com esta linha de pensamento, o cérebro humano não percebe seres estáticos e que não representam perigo.

Os vegetais, entretanto, desempenharam um papel extremamente importante no processo evolutivo, tal qual a preparação da atmosfera do planeta; pois de acordo com a teoria endossinbiótica, células ancestrais teriam dado abrigo a seres procariotos capazes de fazer fotossíntese produzindo alimento e liberando oxigênio no ambiente, fato que possibilitou o surgimento dos seres terrestres como nós e desde então caminhamos na companhia destes seres, cultivando e estudando formas de utilizá-los (BILL LAWS, 2013).

As civilizações chinesa e indiana já apresentavam muitos escritos sobre plantas entre 100 e 200 anos antes de Cristo, porém a mais antiga data de 2800 a.C. (TOMAZZONI et al., 2006). Períodos mais tarde, as grandes navegações e a descoberta de novos continentes levaram a humanidade à elucidação de uma enorme gama de produtos naturais, ou seja, de produtos de origem vegetal devido à biodiversidade encontrada (BRASIL, 2012).

Muitos reis e rainhas foram presenteados e cultivaram plantas que direcionaram o desenvolvimento da nossa história (BILL LAWS, 2013) e, em algum momento, após séculos de convivência, esse contato tão próximo às plantas se perdeu. A urbanização, a industrialização e o desenvolvimento da tecnologia construíram uma barreira que não permite reconhecer os vegetais e sua importância (TOMAZZONI et al., 2006).

De acordo com Salantino e Buckeridge (2016), os seres humanos podem aprender a reconhecer os vegetais, assim como os seus parentes evolutivos conhecidos popularmente como primatas, os quais são capazes de reconhecer folhas e frutos adequados para sua alimentação. Porém, estes tiveram uma aprendizagem voltada para a prática do dia a dia nas florestas, colhendo e provando o que poderia vir a ser seu alimento, enquanto os humanos atualmente têm acesso às folhas, frutos, sementes e raízes por meio da visita ao mercado, em 
que se é capaz de reconhecer apenas partes de uma planta e não o vegetal como um todo (SALATINO e BUCKERIDGE, 2016).

\subsection{ENSINO DA BOTÂNICA}

A Botânica é uma ciência que trata do estudo dos vegetais e está contida na Biologia, que é o estudo da vida. Ambas estão presentes em várias atividades humanas importantes, como na alimentação, na produção e uso de medicamentos, dentre outros, e ainda assim, o tema Botânica não é tratado com relevância na educação. Este problema é justificado pela falta de preparo dos professores enquanto alunos de graduação, quando são expostos a conteúdos meramente descritivos, sem contextualização e prática e com muitos termos botânicos a serem memorizados (MOREIRA et al., 2019).

Ao mesmo tempo, a Botânica tem gerado tão pouco interesse nos estudantes que eles mal conseguem perceber os vegetais como componentes do campo ou objetos decorativos (SILVA et al., 2016; NEVES et al., 2019).

A justificativa para que o ensino-aprendizagem de Botânica seja um obstáculo está relacionada ao uso de termos botânicos de difícil memorização, a conteúdos meramente descritivos e sem atividades práticas, à falta de maior interação com os vegetais, à falta de contextualização e ao uso limitado de tecnologia (URSI et al., 2018; MOREIRA et al., 2019). Estudos revelaram que uma porcentagem significativa de estudantes, cerca de $30 \%$ a $60 \%$, apontam esses mesmos fatores como agentes geradores da grande dificuldade de aprendizado e da falta de interesse pela Botânica (MELO et al., 2012; BATISTA et al., 2015).

Em instituições de ensino superior, algumas vezes, pode ocorrer um grande problema que é a formação insuficiente em Botânica dos graduados em licenciatura, devido à falta de interesse do próprio e à metodologia de ensino tradicional que não abrange as atividades práticas (SENICIATO e CAVASSAN, 2004).

Diante disso, a má formação de um professor tende a proporcionar um ensino medíocre de Botânica, gerando muito desinteresse e tédio nos estudantes, os quais poderão se tornar professores de Biologia no futuro e que poderão transmitir a falácia da Botânica como algo irrelevante, criando um ciclo vicioso do desconhecimento da Biologia Vegetal (TOWATA et al., 2010). Contudo, é evidente que o ensino de Botânica preocupa setores da educação, mostrando a necessidade de se renovar a metodologia educacional (SILVA et al., 2016; FONSECA e RAMOS, 2018). 
Utilizando-se dos aspectos educacionais e efetivos tal qual o ensino por investigação que apresenta meios como o conhecimento científico, o raciocínio lógico para formular hipóteses e as aulas práticas - é possível chegar a uma valorização da formação escolar e a uma aprendizagem que seja relevante (SENICIATO e CAVASSAN, 2004). Os recursos mais importantes para desenvolver e apreender a atenção de uma pessoa são as atividades práticas, sejam elas em laboratório ou em ambientes não formais (NERIS, 2013; MARINHO et al., 2016).

Os espaços não formais de ensino são aqueles que se encontram fora de todas as dependências de uma escola, nos quais é possível desenvolver atividades educativas, seja esse local estruturado e planejado, como os espaços institucionalizados, ou como os espaços não institucionalizados que não dispõem de qualquer estrutura e planejamento para tal, como um jardim botânico ou uma trilha ecológica. (JACOBUCCI, 2008; QUEIROZ et al., 2017; SULZBACH e JOHANN, 2021).

A pluralidade de metodologias e estratégias didáticas organizadas e utilizadas em forma de investigação pode romper com o ensino tradicional, levando a um ensinoaprendizagem participativo e problematizador, no qual os estudantes serão os principais agentes formadores de seus conhecimentos (KOVALSKI e OBARA, 2013).

Salatino e Buckeridge (2016) complementam essa afirmativa, dizendo que a utilização de espécies vegetais em laboratórios e aulas práticas pode apresentar algumas vantagens, como a sua grande disponibilidade, seu fácil acesso e a não imposição de limitações de natureza ética - como por exemplo gerar dor no indivíduo ou maus tratos, permitindo assim a livre utilização de diferentes espécies para inúmeras atividades de estudo e conhecimento, como hortas (CONDE et al., 2014), exsicatas (SILVA et al., 2019) e dissecação (MELO et al., 2020).

\subsection{PLANTAS MEDICINAIS}

A utilização de plantas para o tratamento de doenças é uma prática muito antiga e rica (FARIA e ALBUQUERQUE, 2018) que não se sabe exatamente quando surgiu, dando origem ao que se conhece hoje por "plantas medicinais", tal prática apresenta registros escritos de mais de 2000 anos a.C. (VEIGA JUNIOR et al., 2005; PORTELINHA et al., 2017 ;).

No Brasil, o uso de plantas medicinais de forma oficial foi pensado a partir da Conferência Nacional de Saúde de 1986, mas só foi instituída com a Política Nacional de 
Práticas Integrativas e Complementares (PNPIC), Portaria GM No 971 de 03 de maio de 2006 (PORTELINHA et al., 2017).

De acordo com a Organização Mundial da Saúde (OMS, 2001), cerca de oitenta por cento da população mundial utilizam as plantas de forma a assegurar primariamente os cuidados com a saúde. Cunha (2003) afirma que "embora a medicina tradicional, baseada no uso de ervas medicinais, esteja sustentada em uma história milenar, a partir do século XIX, com a obtenção de substâncias sintéticas com propriedades farmacológicas e com a síntese química de novos compostos, a utilização de derivados de plantas diminuiu consideravelmente." No entanto, a partir da década de 1960, o interesse e a procura por produtos fitoterápicos e as terapias naturais vêm aumentando gradativamente, sejam estes produtos in natura ou processados.

As novas tendências globais de uma preocupação com a biodiversidade e as ideias de desenvolvimento sustentável, em que haja recursos naturais para a população atual e para a população futura, trouxeram novas perspectivas ao estudo das plantas medicinais brasileiras e acabaram despertando um interesse global pela fitoterapia (LORENZI e MATOS, 2008).

\subsection{ESPÉCIES SELECIONADAS PARA ESTE TRABALHO}

A Plectranthus L'Hér. pertence à ordem Lamiales, família Lamiaceae, e suas muitas espécies são originárias da África, da Ásia e da Austrália. No entanto, algumas espécies foram trazidas para o Brasil e são cultivadas comumente, pois se adaptaram muito bem ao clima brasileiro (LUKHOBA et al., 2006; RODRIGUES et al., 2011).

As espécies do gênero Plectranthus que foram selecionadas para este trabalho apresentam diferentes interesses econômicos, elas podem ser utilizadas como ornamental, ou como medicamento e são frequentemente cultivadas em jardins e quintais, dando maior possibilidade de contextualizar sua utilização para os discentes. Além disso, essa espécie apresenta relativa facilidade de observação de seus órgãos no microscópio sem a utilização de corantes (ALBUQUERQUE et al., 2007).

Para este trabalho, foram selecionadas duas espécies de Plectranthus: Plectranthus barbatus Andrews e Plectranthus scutellarioides (L.) R. Br. P. barbatus é um arbusto com cerca de um metro, com folhas pecioladas, elípticas e aveludadas (Figura 1), popularmente conhecida como malva-santa, boldo-do-Brasil, boldo falso, dentre outros nomes menos populares (ALBUQUERQUE et al., 2007). Na utilização medicinal, a ciência tem estudado 
principalmente diterpenos, óleos essenciais e fenólicos encontrados nessas espécies vegetais (ABDEL-MOGIB et al., 2002).

Figura 1 - Plectranthus barbatus Andrews.

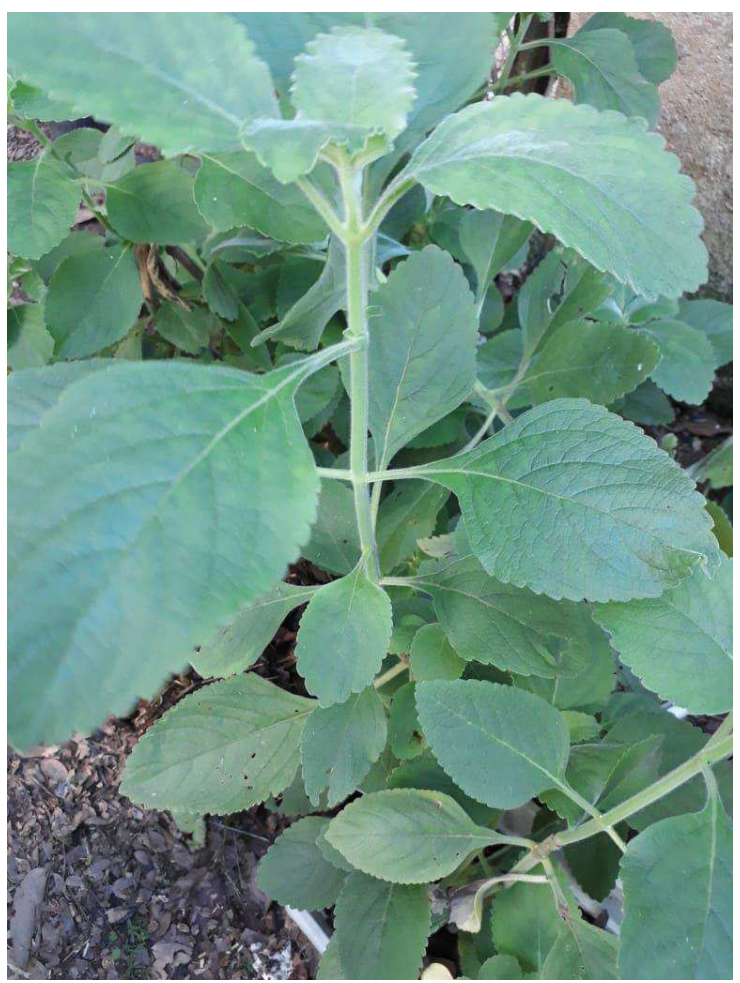

Fonte: Próprio autor (2021).

Os diterpenos são metabolitos especiais produzidos no organismo vegetal, que apresentam uma cadeia de vinte carbonos (Figura 2). De acordo com Abdel-Mogib e colaboradores (2002), cento e quarenta diterpenoides foram identificados em Plectranthus sp.. $\mathrm{Na}$ medicina popular, os diterpenos encontrados nesse gênero são capazes de tratar problemas gástricos, intestinais, hepáticos, entre outros (LUKHOBA et al., 2006).

No gênero Plectranthus, mais precisamente em P. barbatus, foram isolados metabolitos especiais como barbatusina, ciclobutatusina, 6 - $\beta$-hidroxicarnoso, barbatuso, plectrina, cariocal, coleon E, coleon F, plectrinona A, plectrinona B, e $12,9(10 \rightarrow 20)$-abeoabieta-8,11,13-trien-10ß,11,12-triol, que apresentam grande importância farmacológica ou química, além de propriedades biológicas comprovadas (ALBUQUERQUE et al., 2007). 
Figura 2 - Esqueletos básicos de diterpenos.
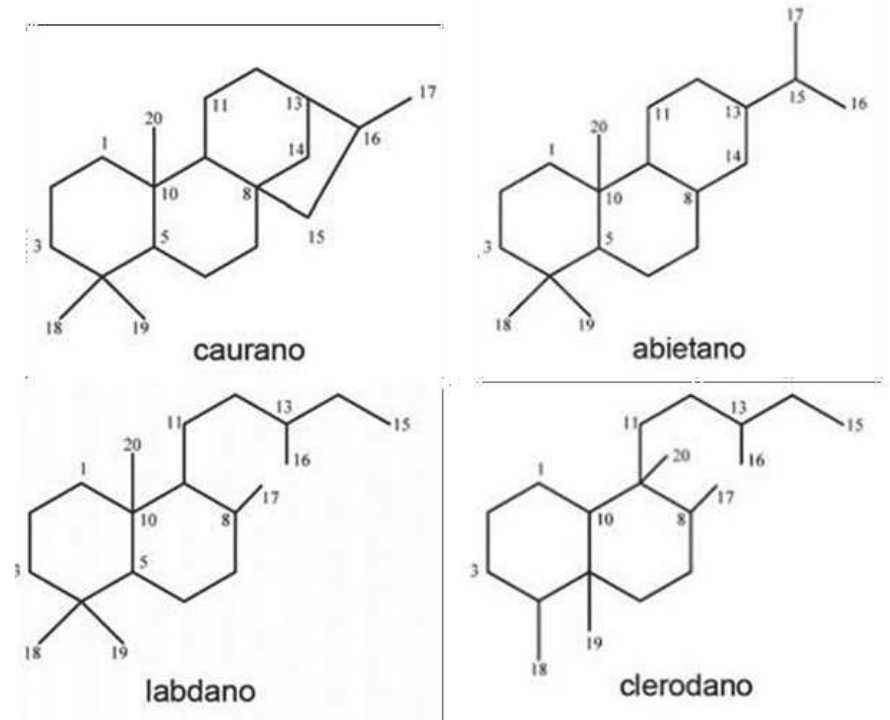

Fonte: Maciel et al. (2006).

Conforme explícito no trabalho de Lukhoba e colaboradores (2006), um diterpeno do tipo labdano encontrado na espécie $P$. barbatus é a forskolina, que é capaz de ativar diretamente a adenil-ciclase que é uma enzima que hidrolisa ATP (adenosina trifosfato), modulando o AMPc (adenosina monofosfato cíclico) que participa de várias reações celulares, ou seja, pode aumentar ou inibir o metabolismo celular. Esse processo pode ativar secreções gástricas devido à presença da forskolina, melhorando a digestão e explicando por que o extrato dessa planta é usado para tratar distúrbios gástricos. Ainda sobre a at ivação da adenilato ciclase, Mukherjee e colaboradores (2000) afirmam que a presença desse diterpenoide pode reduzir a pressão intraocular, a pressão sanguínea e apresentar efeito antiinflamatório.

A segunda espécie, P. scutellarioides é conhecida no Brasil com os nomes populares de coleus ou tapete e seu interesse está voltado para a ornamentação (MENG et al., 2016), pois apresenta uma folha oval com base arredondada que gera uma leve semelhança com um coração, salientando também bordas coloridas, como exposto na Figura 3 (ITO et al., 2018). No entanto, de acordo com Levita e colaboradores (2016), esta espécie originária da região sudeste da Ásia e da Indonésia também pode ser usada como medicamento para curar várias doenças, pois estudos mostram que ela apresenta ação anti-inflamatória (CRETTON et al., 2018) e que contém constituintes químicos com atividade contra células tumorais in vitro (ITO et al., 2018). 
Figura 3 - Plectranthus scutellarioides (L.) R. Br.

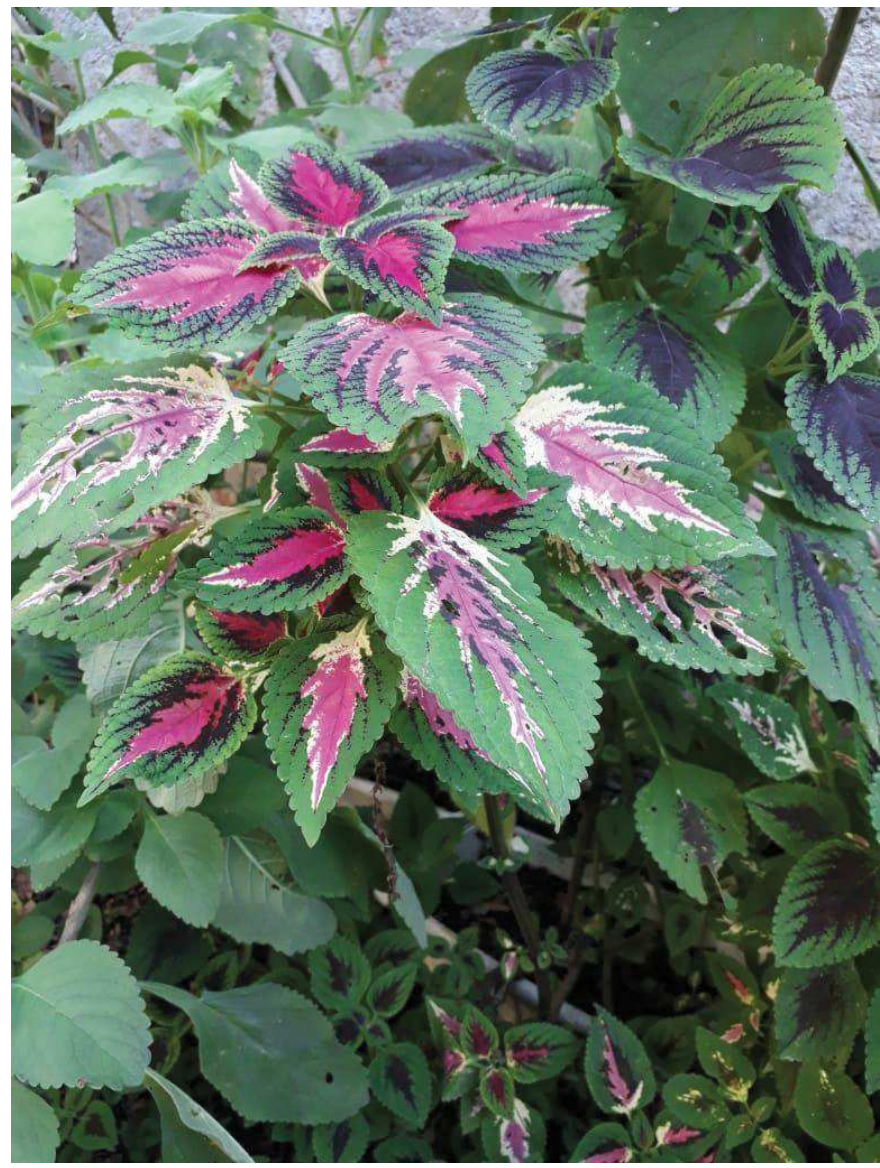

Fonte: Próprio autor (2021).

Considerando-se os pontos descritos de dificuldades, de possibilidades e a preocupação com o ensino da Botânica suscitado por diversos autores, como Towata e colaboradores (2010), torna-se oportuno o desenvolvimento de um trabalho empregando o cultivo de plantas medicinais. Essas plantas puderam ser usadas pela comunidade escolar, além de serem preparadas para as atividades práticas, com a finalidade de captar atenção, de aguçar a curiosidade e de permitir o reconhecimento e a aprendizagem da biologia vegetal pelos alunos do Ensino Médio. Desta forma, é possível mostrar a importância da construção das aulas relacionada à aprendizagem contextualizada (SENICIATO e CAVASSAN, 2004), que por fim, corrobora ideias de formação pessoal e social dos alunos (CACHAPUZ, PRAIA e JORGE, 2004; LOPES e BETTENCOURT, 2009).

\subsection{REFERENCIAL TEÓRICO}

A metodologia desse estudo foi criada a partir de uma análise das dificuldades de ensino no contexto da Botânica. Portanto, foram pesquisados os termos mais citados na 
bibliografia consultada e com base em trabalhos que apresentavam dificuldades de aplicação, foi realizada uma categorização destes desafios (Quadro 1).

Quadro 1 - Categorização das dificuldades do ensino de Botânica realizada a partir de levantamento bibliográfico.

\begin{tabular}{|c|l|}
\hline \multicolumn{2}{|c|}{ Categorias de dificuldades do ensino de Botânica } \\
\hline 1 & Desinteresse do aluno \\
\hline 2 & Desinteresse do professor \\
\hline 3 & Falta de atividades práticas \\
\hline 4 & Falta contextualização \\
\hline 5 & Cegueira botânica \\
\hline
\end{tabular}

Fonte: Próprio autor (2020).

Os desafios foram pesquisados nos bancos de dados: Scielo, Portal de Periódicos CAPES/MEC e Google Acadêmico, devido à praticidade de sua utilização, a partir do título dos artigos com as palavras-chave: aprendizagem de biologia vegetal, ensino de biologia, ensino de botânica, dificuldades de ensino de botânica. Em princípio, foram encontrados nessa busca, um total de 29.000 trabalhos como artigos, resumos e teses, observando os títulos a serem descartados, que não tratavam de educação em Botânica, o número de trabalhos diminuiu para cerca de 2.000. Destes, 61 foram escolhidos considerando o assunto encontrado na leitura do resumo.

De acordo com a revisão bibliográfica realizada sobre o ensino de Botânica, foi observado que algumas dificuldades no ensino-aprendizagem são recorrentes (Figura 4) e estão relacionadas diretamente à cegueira botânica (NEVES, 2019; COSTA et al., 2019), apesar de esta ser citada menos vezes, pouco mais de $10 \%$. 
Figura 4 - Porcentagem de citações das dificuldades no ensino da Botânica obtida a partir de levantamento bibliográfico.

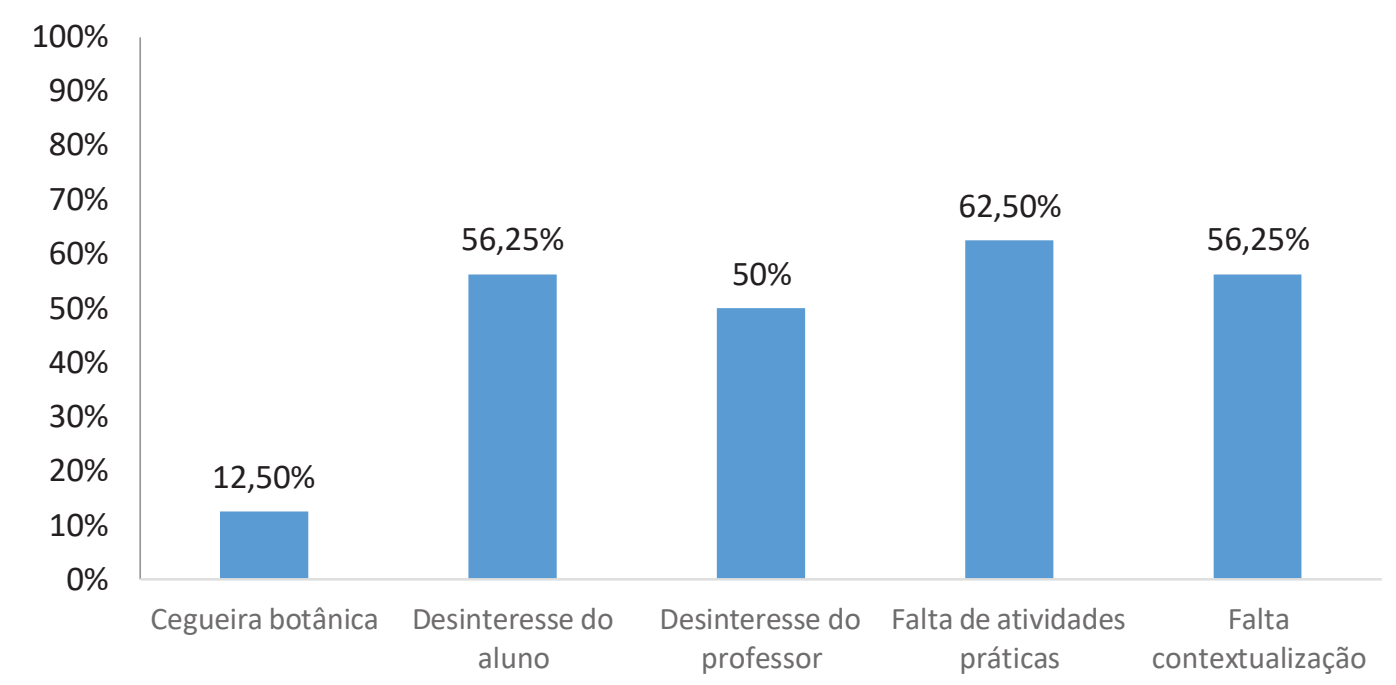

Fonte: Próprio autor (2020).

As dificuldades de ensino sobre os vegetais estão relacionadas entre si por meio do método tradicional de ensino nas escolas e também nas unidades de ensino superior, que leva ao desânimo dos estudantes, à insegurança dos professores, ao desconhecimento prático do assunto e, por fim, à cegueira botânica (BARBOSA et al., 2020; ARAÚJO, 2020; BARBOSA et al., 2020).

O ensino pode ser organizado para que essas dificuldades sejam sanadas por meio da utilização de uma metodologia conhecida como sequência didática, que é um conjunto de atividades articuladas e planejadas com a intenção de atingir um determinado objetivo (ARAÚJO, 2013). Neste caso, transformar a educação tradicional em uma educação de maior qualidade e prestígio no ensino de Botânica.

A sequência didática é um processo de ensino que deve ser estruturado em uma série de etapas: com a apresentação do tema aos estudantes para que saibam do que se trata, em um segundo momento com uma produção inicial em que o estudante expõe seu conhecimento sobre o assunto, depois com os módulos, que são atividades diversificadas para desenvolver o tema e, por fim, com uma a produção final em que os discentes possam pôr em prática o que aprenderam, como por exemplo produzir um modelo de tecidos vegetais (MIQUELANTE et al., 2017).

Dessa forma a sequência didática propõe algumas práticas escolares capazes de valorizar e de promover uma aprendizagem profunda, pois entretém o estudante com os conteúdos que ele precisa aprender (CORTE et al., 2018). 


\section{OBJETIVOS}

\subsection{GERAL}

O objetivo do presente estudo foi produzir uma sequência didática que se fundamentasse no cultivo de plantas medicinais e na utilização de seus órgãos vegetais em aulas práticas para desenvolver o interesse e o conhecimento pelo estudo de Botânica.

\subsection{ESPECÍFICOS}

- Engendrar uma sequência didática que permita a qualquer professor reproduzir as atividades em outras escolas e instituições de ensino e moldá-la de acordo com sua realidade.

- Inserir os estudantes no aprendizado científico.

- Conquistar a atenção e o interesse dos discentes sobre os vegetais.

- Socializar a real importância das plantas para a vida.

-Validar essa sequência didática por professores de Biologia do Ensino Médio. 


\section{METODOLOGIA}

\subsection{AUTORIZAÇÃO DE COMITÊ DE ÉTICA}

Este trabalho foi aprovado no Comitê de Ética em Pesquisa com Seres Humanos da UFJF, conforme parecer número 4.561.645 e CAAE: 32700519.5.0000.5147.

\subsubsection{LOCALIZAÇÃO}

A sequência didática a ser avaliada por professores de escolas públicas foi construída usando como base as características da realidade encontrada no Colégio Estadual Almirante Rodrigues Silva, localizado na Rua Allan Kardec $n^{\circ}$ 254, bairro de Fátima, município de Valença, RJ, como mostra o mapa da Figura 5.

Figura 5 - Mapa de localização do Município de Valença, Estado do Rio de Janeiro onde se localiza o Colégio Estadual Almirante Rodrigues Silva, cenário de desenvolvimento da intervenção "Plantas Medicinais na Aprendizagem de Botânica do Ensino Médio".

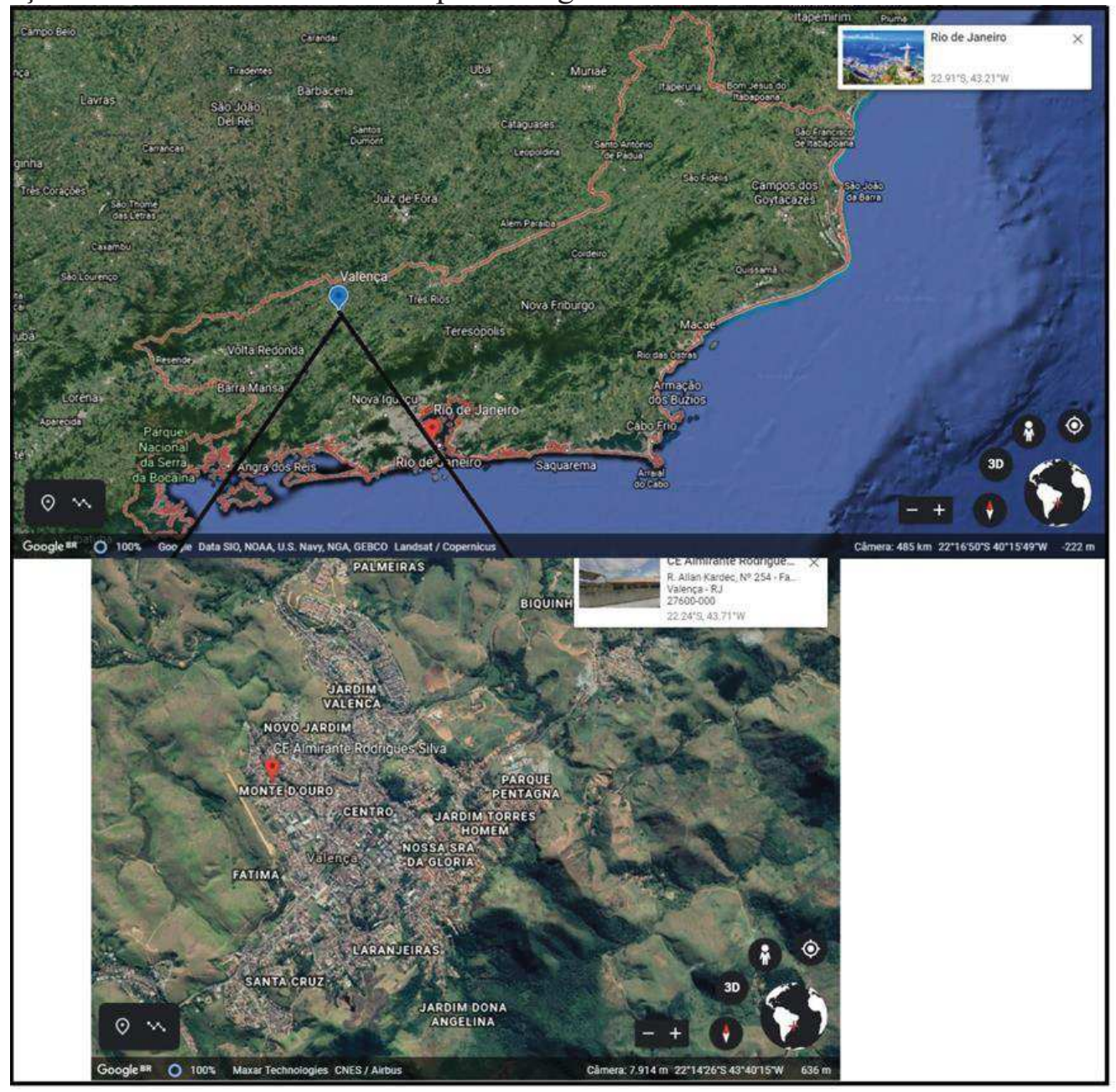

Fonte: Google Earth Acessado em 08/04/2020 às 22:30h. 


\subsubsection{HISTÓRIA DA ESCOLA}

A instituição de ensino em que este trabalho foi desenvolvido foi criada com o Decreto $\mathrm{n}^{\mathrm{o}} 11.807$ de 07 de junho de 1965, depois de ter sido chamada de Escola "Lar José Fonseca" e ter funcionado no Prédio do Antigo Abrigo de Meninos, do mesmo nome do Lar, situado ao lado da Praça Visconde do Rio Preto. De 1965 até 2012 foi Escola Estadual, oferecendo apenas o Ensino Fundamental, em 2013 foi criada a primeira turma de Ensino Médio, passando desta forma à categoria de Colégio Estadual. Por ocasião de seus 50 anos, em 2015, foi elevado a Colégio de Referência do Estado do Rio de Janeiro, tendo em 2016 sua primeira turma de Ensino Médio de referência.

Nessa nova fase, com uma estrutura totalmente diferente de ensino, os estudantes passaram a contar com uma área de conhecimento então desconhecida, chamada de núcleo articulador, o qual trazia em sua essência os componentes curriculares denominados de estudos orientados, projeto de pesquisa e intervenção e projeto de vida. Essa nova área de conhecimento tem a finalidade de trabalhar o socioemocional dos alunos, preparando-os para a vida e para o mercado de trabalho. Esse novo formato de educação exigiu que o colégio funcionasse em tempo integral e com a denominação de Escola Integral.

\subsubsection{PÚBLICO}

A sequência didática foi desenvolvida para turmas de Primeiro Ano do Ensino Médio, para as quais o conteúdo de Botânica se apresenta com o nome de Anatomia Vegetal. No entanto, esse método pode ser reproduzido para outros anos escolares, fazendo-se as devidas alterações e adaptações necessárias relativas à realidade de cada turma e escola.

\subsubsection{DESENVOLVIMENTO DA SEQUÊNCIA DIDÁTICA}

A sequência didática está dividida em quatro etapas, além da avaliação, e está explicitada no ANEXO - Produto, na página 51.

No primeiro momento da execução da atividade ocorre a aplicação de um questionário semiestruturado (ALEXIADES, 1996), construído especificamente para este trabalho pelo próprio autor (APÊNDICE A), para investigar o que os alunos pensavam sobre os vegetais de uma forma geral. 
O momento seguinte constituiu-se de uma aula dialogada (FERNANDES e SILVA, 2017) sobre plantas e sua importância, utilizando para isso alguns questionamentos básicos sobre Botânica, de fácil reflexão e de fácil pesquisa (Quadro 2), com a finalidade de provocar os alunos a raciocinarem, buscarem respostas e produzirem novas perguntas por meio da construção dos seus conhecimentos.

Quadro 2 - Questões utilizadas na aula dialogada para envolver e instigar os estudantes a terem uma participação ativa.

\begin{tabular}{|c|l|}
\hline 1 & O que é Botânica? \\
\hline 2 & Como as plantas surgiram? \\
\hline 3 & Qual a importância das plantas? \\
\hline 4 & Qual a relação da humanidade com as plantas? \\
\hline 5 & O que é cegueira botânica? \\
\hline
\end{tabular}

Fonte: Próprio autor (2020).

A conversa expositiva discorre sobre a importância dos seres fotossintetizantes, como eles desempenharam um papel dinâmico no desenvolvimento da vida na Terra, como fizeram parte das vidas humanas no passado e com ainda fazem atualmente, como são funcionais para o planeta e para o meio ambiente, e como pode ser prejudicial para o planeta se não cuidarmos deles. Depois os estudantes fizeram buscas de artigos (CAVALCANTE et al., 2018), usando a internet no laboratório de informática, sobre as duas espécies vegetais que foram escolhidas para este trabalho, Plectranthus barbatus Andrews e Plectranthus scutellarioides (L.) R. Br.

Outras espécies poderiam ter sido escolhidas, mas a facilidade para operar cortes anatômicos e de visualização no microscópio devem ser avaliadas. A busca por artigos foi feita pelos sites Scielo e Google Acadêmico, por serem mais conhecidos e fáceis de usar, com o objetivo de descobrir um pouco das características das espécies selecionadas. Para uma maior contextualização das espécies escolhidas, com fins motivacionais, foram exibidos, antes da busca de artigos, áudios e imagens feitos pelo coordenador do projeto Arranjo Produtivo Local de Plantas Medicinais do Palácio Itaboraí, Sérgio da Silva Monteiro, do Fórum Itaboraí, FIOCRUZ em Petrópolis - Rio de Janeiro.

Com isso, ao fim desta etapa e com a construção do conhecimento por parte dos alunos iniciou-se a aula prática que contextualizaria os vegetais e o conteúdo de Anatomia Vegetal à vida dos discentes (SOUSA, 2019), mostrando uma possível solução para o problema da cegueira botânica. 
A prática teve início com a criação de um ambiente de cultivo, o qual foi construído em um espaço externo do Colégio, utilizando as espécies conhecidas popularmente como boldo (Plectranthus barbatus Andrews) e tapete (Plectranthus scutellarioides (L.) R. Br) exibidas na Figura 6. Essas espécies foram selecionadas para esse trabalho por apresentarem fácil cultivo, grande utilização por uma parcela da sociedade, considerando seus interesses químicos e farmacológicos, além de facilidade de confecção e visualização dos cortes histológicos feitos à mão livre.

Figura 6 - Exemplos das plantas selecionadas para a prática do trabalho "Plantas Medicinais na Aprendizagem de Botânica do Ensino Médio". A: Plectranthus barbatus Andrews boldo. B: Plectranthus scutellarioides (L.) R. Br - tapete.

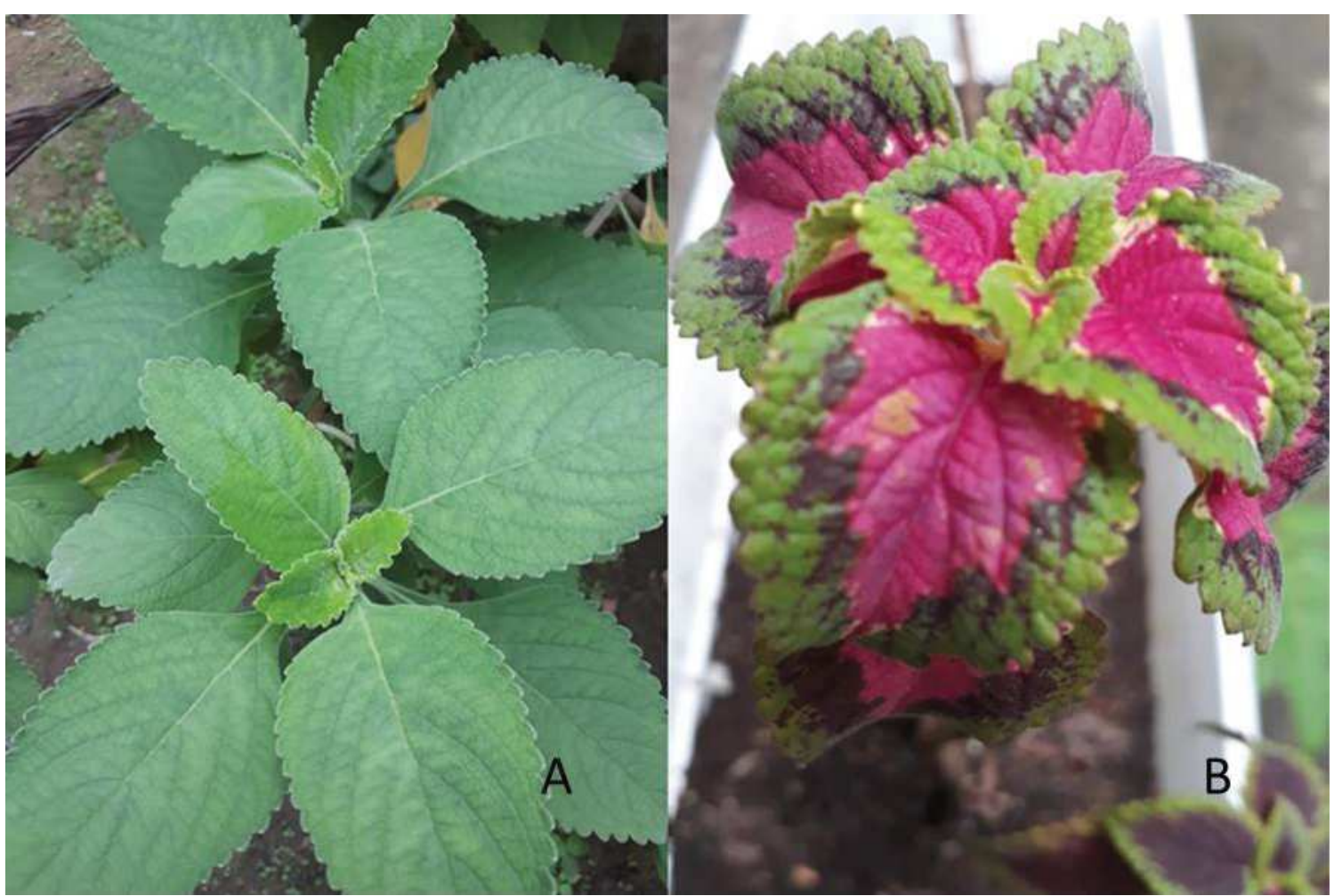

Fonte: Próprio autor (2020).

As duas espécies selecionadas para esse trabalho foram cultivadas em seis jardineiras de plástico com capacidade de 24 litros que continham brita cobrindo o fundo do vaso, cerca de $20 \%$, areia preenchendo os espaços entre as britas e cobrindo-as, cerca de $25 \%$, e por cima destes dois elementos terra preta, cerca de $45 \%$, tendo a camada mais superficial terra vegetal, cerca de 10\%, para o plantio dos vegetais (Figura 7), processo baseado nas cartilhas da Composta São Paulo (2014) e da EMATER do Estado do Pará (2020). 
Com essa iniciativa, foi possível desenvolver o processo de ensino-aprendizagem, uma vez que os estudantes estiveram à frente de todo o procedimento de preparação e cultivo, enquanto o professor fornecia as orientações. Além disso, puderam atender às pessoas da comunidade escolar que queriam estas plantas para uso particular.

Figura 7 - Representação da montagem das jardineiras contendo brita (A) para cobrir o fundo do vaso, areia (B) preenchendo os espaços entre as britas e finalizando com terra preta (C) e a camada mais superficial de terra vegetal (D) para inserção dos vegetais.
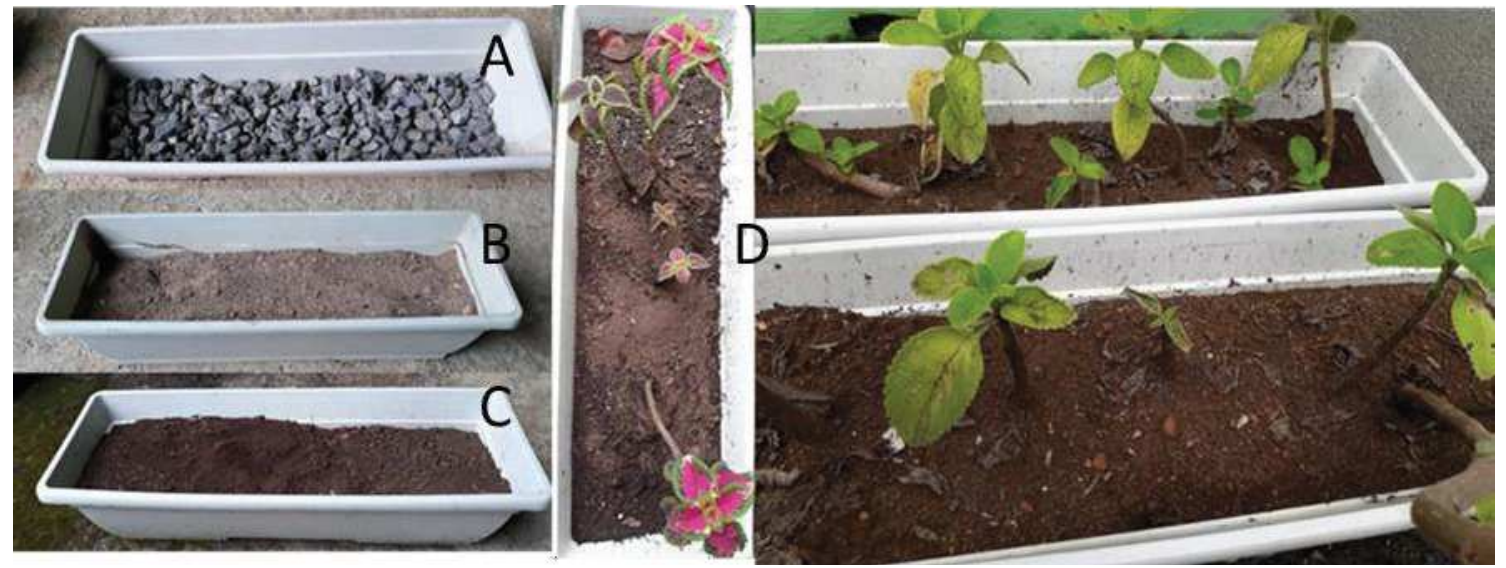

Fonte: Próprio autor (2020).

Foram elaboradas lâminas histológicas usando lâminas de barbear em cortes à mão livre, que obtiveram secções transversais e longitudinais dos caules, raízes e folhas das plantas cultivadas para a utilização no microscópio, patrimônio do Laboratório de Ciências da Natureza do Colégio.

Este processo teve por finalidade construir modelos de diferentes tecidos vegetais observados em microscópio, que foram manufaturados com o emprego de massa de modelar e que contribuíram para a construção do conhecimento e para a fixação do conteúdo estudado.

\subsection{COLETA DE DADOS}

A sequência didática (ANEXO), produto do presente estudo, foi enviada em conjunto com o link do formulário Google por e-mail a todos os coordenadores locais do PROFBIO, que encaminharam-no a todos os mestrandos e alunos egressos do Programa. Sendo assim, todos os 61 participantes que se voluntariaram, em todo o território nacional, são professores do Ensino Médio da rede pública. Eles responderam ao formulário no qual o processo de 
ensino-aprendizagem citado foi validado por meio de um questionário semiestruturado (ALEXIADES, 1996) localizado no Apêndice B e representado na Figura 8.

Figura 8 - Representação do questionário semiestruturado respondido pelos professores de Ensino Médio vinculados ao Profbio.

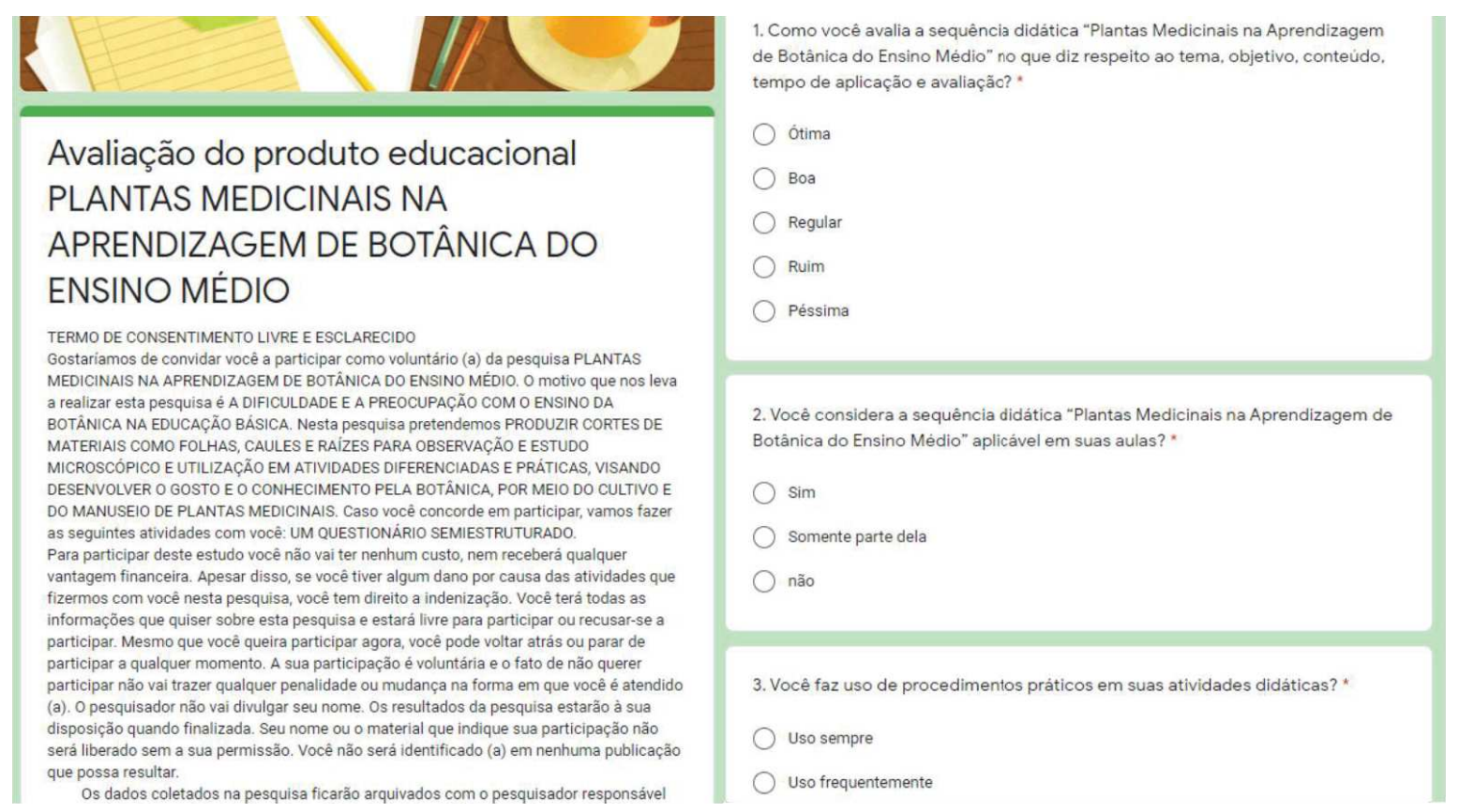

Fonte: Próprio autor (2021).

Os riscos para os participantes são mínimos. Existe o risco de perda de confidencialidade, porém, para minimizá-lo, quando necessário, os participantes foram identificados por pseudônimos ou códigos, a fim de preservar suas identidades; além disso, os dados foram manipulados apenas pelos pesquisadores. Caso algum participante se sentisse constrangido ou incomodado em responder alguma questão, foi-lhe garantido o direito de interromper sua participação na pesquisa.

Critérios de inclusão: Os participantes desta pesquisa deveriam ser professores de Ensino Médio da rede pública, vinculados ao Mestrado Profissional em Ensino de Biologia e responderam o termo de consentimento livre e esclarecido, assim como o formulário semiestruturado de forma remota.

Critérios de exclusão: Os professores que, porventura, não se s sentiram à vontade para participar, ou que não concordaram, ou ainda que apresentaram algum tipo de impedimento. 


\section{RESULTADOS E DISCUSSÃO}

O grande desafio da educação pública brasileira é conseguir, diariamente, um ensinoaprendizagem efetivo com uma formação humana mais ampla. No Colégio Estadual Almirante Rodrigues Silva, para o qual o presente estudo foi pensado em princípio, reuniões semanais têm sido feitas com o objetivo de analisar as dificuldades do aluno a fim de elaborar estratégias que possibilitem maior desenvolvimento e aprendizagem.

O material utilizado para a modalidade de educação integral desta escola foi desenvolvido para que os professores construíssem métodos para atingir uma educação mais contextualizada e com vista para o protagonismo dos estudantes. Esses parâmetros correspondem a LDB/96, que diz que a aprendizagem no Ensino Médio deve ser orientada no sentido de uma maior formação humana, pautada na ética, na autonomia intelectual, no pensamento crítico e com maior contextualização dos conteúdos por meio da relação entre a teoria e a prática na escola. Essas questões atreladas à necessidade de ensinar Botânica e diminuir a cegueira botânica levaram à criação da sequência didática proposta neste trabalho.

A sequência didática aqui elaborada leva em consideração os Parâmetros Curriculares Nacionais do Ensino Médio (PCNEM, 2000) os quais orientam que a educação deve visar o desenvolvimento da curiosidade e o gosto pelo aprender. Desta forma, este trabalho tem como objetivo aprimorar a prática dos professores relativa ao conteúdo de Anatomia Vegetal de forma diferenciada, permitindo aos estudantes desenvolverem o gosto pelas espécies vegetais e serem protagonistas na busca por conhecimento, com o intuito de se minimizar a cegueira botânica.

O formulário semiestruturado apresentou a seguinte pergunta: Como você avalia a sequência didática "Plantas Medicinais na Aprendizagem de Botânica do Ensino Médio" no que diz respeito ao tema, ao objetivo, ao conteúdo, ao tempo de aplicação e de avaliação? (Figura 9). Os dados adquiridos mostram que mais de 90\% dos participantes da pesquisa aprovaram a sequência didática como recurso em aulas de Botânica. De acordo com Anjos e colaboradores (2021), é de extrema importância criar recursos para melhorar o ensino da Botânica, apontando como caminho a contextualização do conteúdo, a discussão do assunto com os estudantes e seus conhecimentos prévios, bem como a utilização de plantas medicinais e seus saberes populares. 
Figura 9 - Resultados sobre a avaliação da sequência didática no que diz respeito ao tema, ao objetivo, ao conteúdo, ao tempo de aplicação e de avaliação.

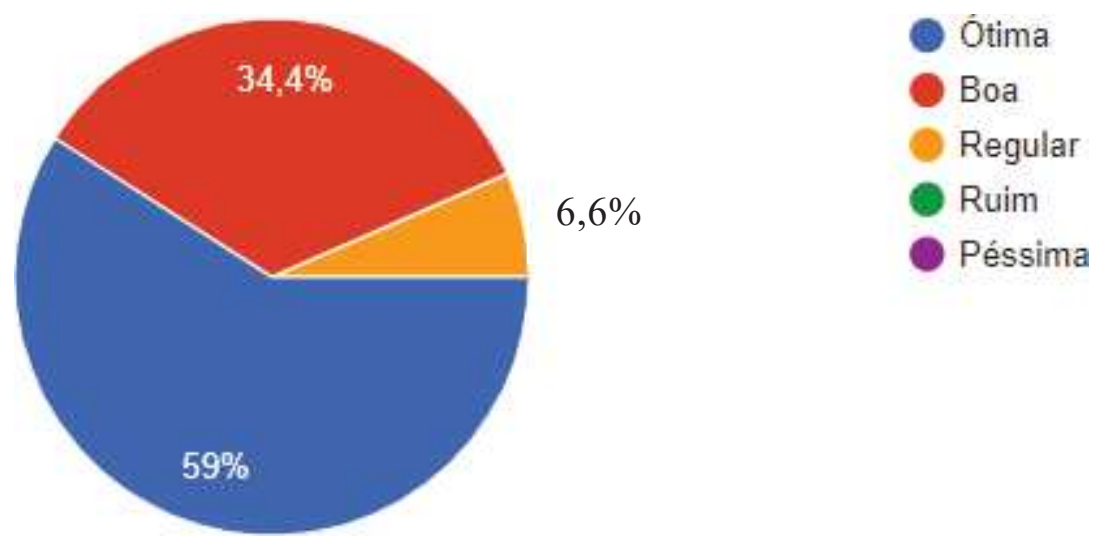

Fonte: Próprio autor elaborado com Google forms (2021).

Quando os participantes da pesquisa foram perguntados: Você considera a sequência didática "Plantas Medicinais na Aprendizagem de Botânica do Ensino Médio" aplicável em suas aulas (Figura 10)? 73,8\% responderam que sim, 24,6\% responderam que só parte dela seria aplicada e apenas 1,6\% responderam que não. Esses dados mostram que, respeitando os diferentes cenários da educação e os diferentes recursos disponíveis em cada região, a sequência didática seria aplicada por mais de $90 \%$ dos participantes. Tal fato pode ser exemplificado com o relato de um participante: "A sequência é totalmente passível de ser aplicada e capaz de ressaltar o protagonismo dos alunos".

Figura 10 - Resultados sobre a avaliação da aplicabilidade da sequência didática.

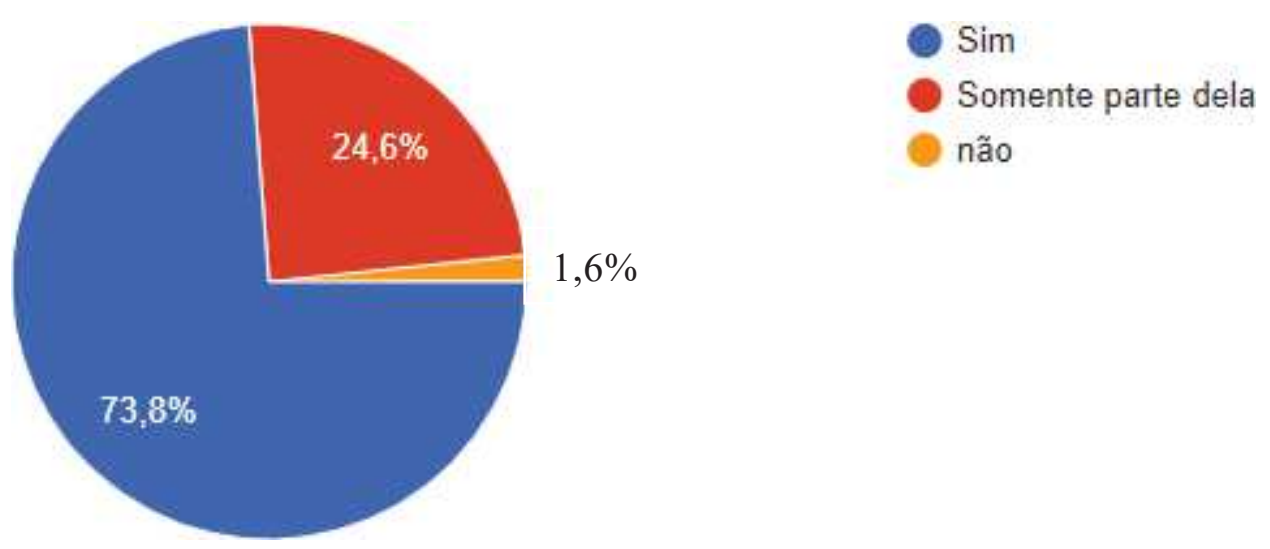

Fonte: Próprio autor elaborado com Google forms (2021).

Ao analisar a questão: Você faz uso de procedimentos práticos em suas atividades didáticas (Figura 11)? Os participantes da pesquisa mostraram que 1,6\% sempre fizeram uso, 
$37,7 \%$ usam com frequência, 45,9\% usam esporadicamente, $11,5 \%$ usam raramente e 3,3\% não fazem uso dessas atividades.

Desta forma, foi possível concluir que mais de $60 \%$ dos professores participantes comprovam os problemas observados nesta pesquisa por não atuarem com atividades práticas tanto quanto poderiam. Fazendo com que o ensino de Botânica não seja satisfatório e atrelado a isso está a pouca utilização de aulas práticas (MELO et al., 2020). Cabe ressaltar que é um grande problema para o professor conseguir sair do modelo tradicional de ensino (DOURADOS E ALMEIDA, 2021).

Figura 11 - Resultados sobre a avaliação do uso de procedimentos práticos.
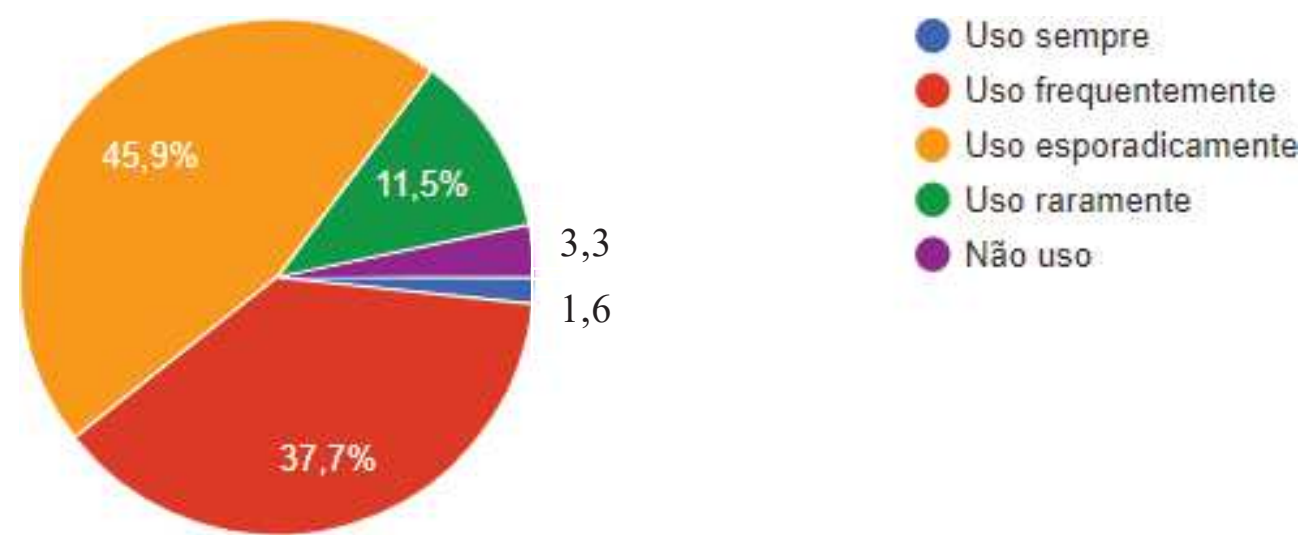

Fonte: Próprio autor elaborado com Google forms (2021).

Como resposta a não utilização de procedimentos práticos: Se você não utiliza procedimentos práticos, indique o (s) motivo (s). Você pode marcar mais de uma alternativa nesta questão (Figura 12). 24,2\% dos participantes responderam falta de preparo para as atividades, 45,5\% responderam haver pouco tempo de aula, 54,5\% responderam que falta espaço físico para as práticas e 51,5\% responderam que há um excesso de conteúdo a ser ensinado em pouco tempo, apontando que em muitos casos o próprio sistema de ensino atrapalha a aplicação dessas atividades práticas e que é de grande importância haver mais discussão acerca do currículo e dos diferentes contextos escolares para se chegar a um ponto de equilíbrio que favoreça a educação. De acordo com Dutra e Güllich (2016), é de grande importância, porém nada fácil, discutir o currículo, pois assim é possível entender as complexidades do ambiente escolar. 
Figura 12 - Resultados sobre a avaliação da não utilização de procedimentos práticos.

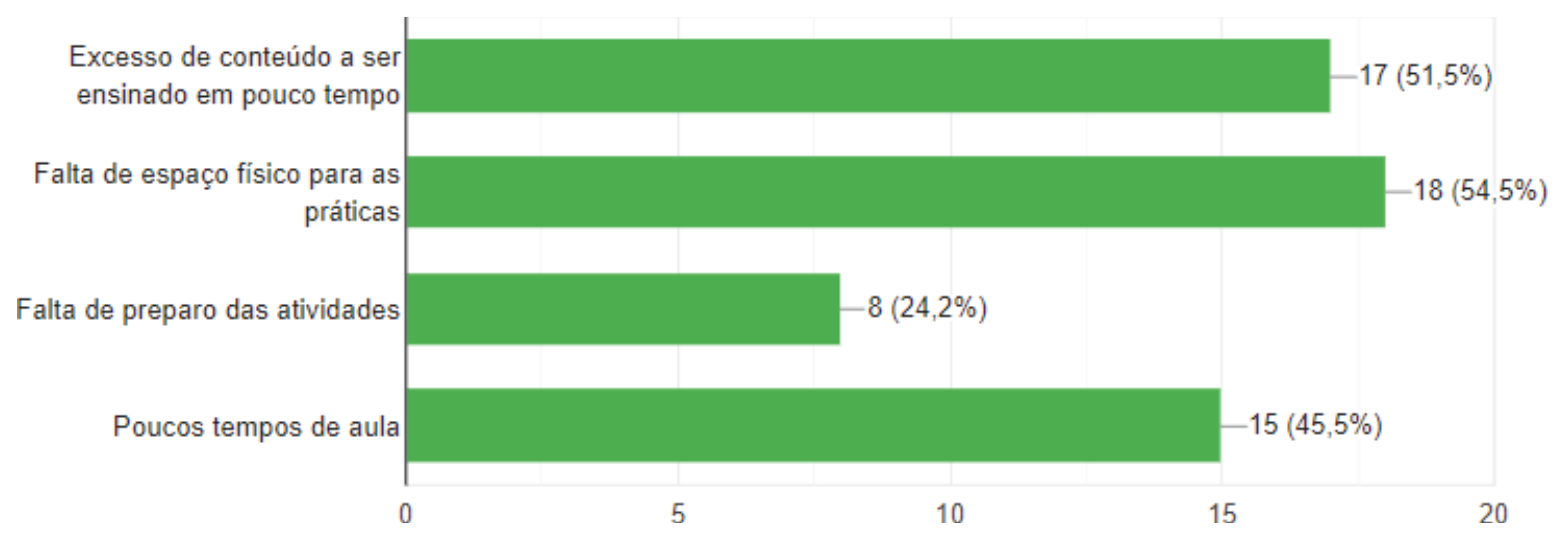

Fonte: Próprio autor elaborado com Google forms (2021).

A pergunta de número cinco do questionário semiestruturado foi: Se você utiliza procedimentos práticos avalie sua experiência (Figura 13). As respostas mostraram que 32,7\% disseram ser ótima, $54,5 \%$ disseram ser boa, $12,7 \%$ disseram ser regular e nenhum dos participantes da pesquisa relatou experiências ruins e, ou, péssimas. Essas porcentagens revelam que as atividades práticas são recursos que levam a um maior sucesso no ensinoaprendizagem por promover a participação dos discentes e estimular a investigação (GONÇALVES et al., 2018; RIBEIRO et al., 2020).

Figura 13 - Resultados sobre a avaliação da utilização de procedimentos práticos.

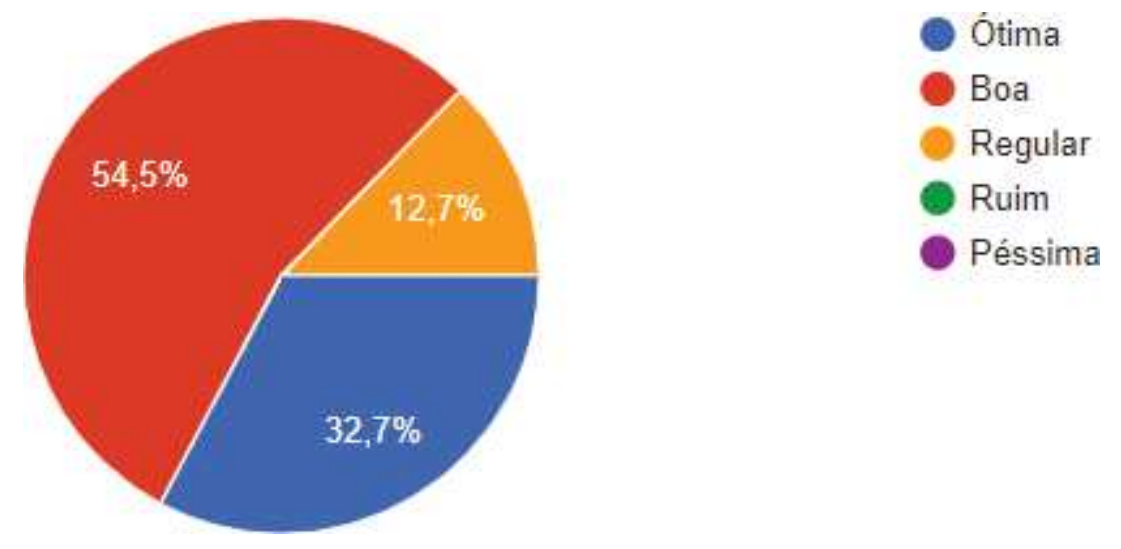

Fonte: Próprio autor elaborado com Google forms (2021).

Os professores participantes desta pesquisa também avaliaram: Sobre a metodologia apresentada, você considera possível reproduzi-la (Figura 14)? Destes, 70,5\% responderam que pode ser reproduzida sim em sua totalidade e $29,5 \%$ responderam que apenas parte dela, 
ou seja, $100 \%$ dos integrantes da pesquisa sinalizaram ser esta uma metodologia adequada às inovações necessárias ao ensino, sendo inclusive uma boa alternativa de transformação da aprendizagem e de contextualização do conteúdo. Santos (2017) descreveu em seu trabalho que estudantes que participaram de atividades práticas e da construção de materiais didáticos interagiram melhor com conteúdos de Botânica, os quais antes eram considerados difíceis e desinteressantes. O trabalho realizado por Silva e colaboradores (2019) reforça que quanto maior a contextualização e a participação ativa dos estudantes maior é a aprendizagem significativa.

Figura 14 - Resultados sobre a avaliação sobre a reprodução da metodologia apresentada.

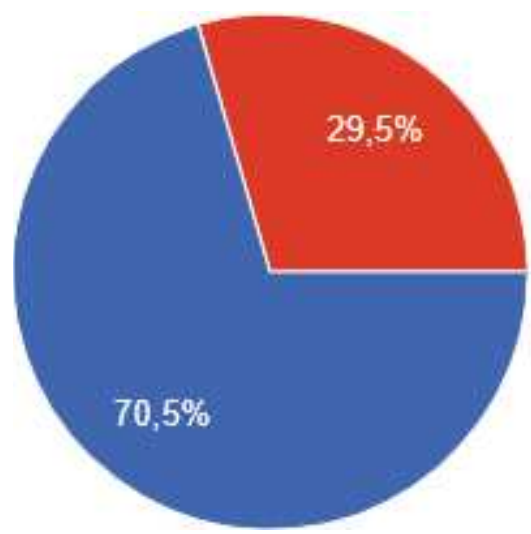

Sim, totalmente

Sim, em parte

Não

Fonte: Próprio autor elaborado com Google forms (2021).

O questionamento seguinte foi: Sobre o cultivo das plantas e a confecção de lâminas histológicas, você considera que a atividade incentivaria o protagonismo dos seus alunos (Figura 15)? 49,2\% consideram que essas atividades incentivam o protagonismo, 45,9\% acham que incentivaria a maioria dos estudantes, $4,9 \%$ acham que não incentivaria a maioria deles e nenhum dos partícipes mencionou que essas atividades não seriam incentivadoras do protagonismo. Como relatado, no trabalho de Santos e colaboradores (2018), os estudantes que constroem seus objetos de estudo saem da passividade ganhando autonomia e se tornam os sujeitos principais da própria educação. 
Figura 15 - Resultados sobre a avaliação do cultivo das plantas e da confecção de lâminas histológicas em relação ao protagonismo.

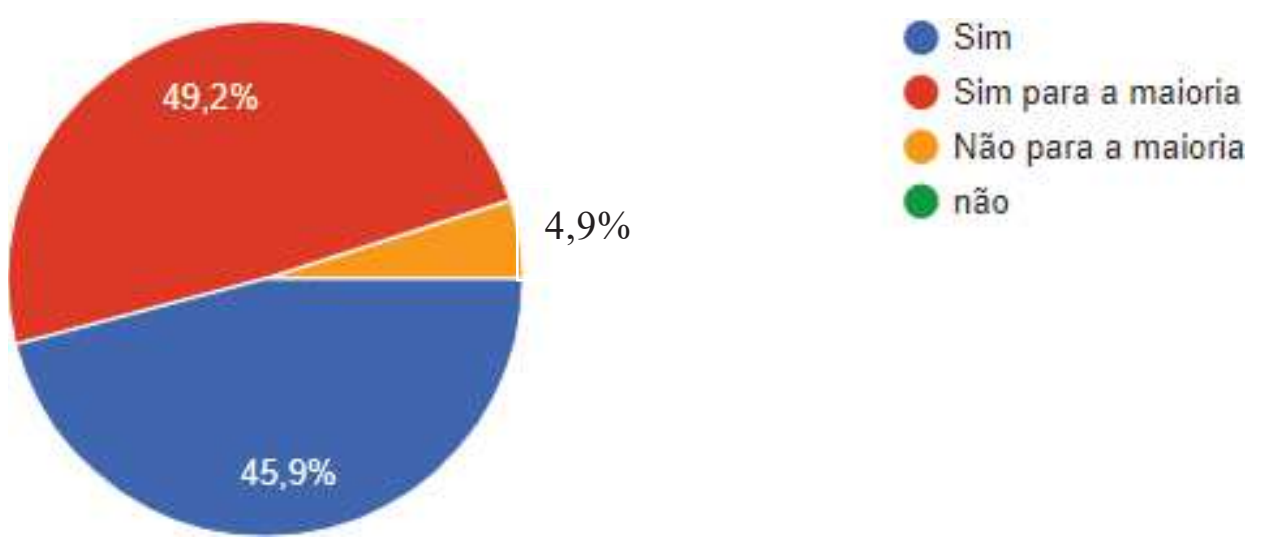

Fonte: Próprio autor elaborado com Google forms (2021).

Para analisar se a sequência didática é um instrumento útil perguntou-se: Considerando a sua realidade de trabalho e aplicando uma escala de 1 para não útil a 5 para muito útil, que nota você daria para a sequência didática (Figura 16)? Esses dados mostram que $100 \%$ dos professores integrantes da pesquisa acham essa sequência útil, sendo que praticamente metade deles $49,20 \%$ acharam-na muito útil.

Esse resultado demonstra que a sequência didática construída é um recurso de grande potencial para se trabalhar o ensino-aprendizagem, pois tem a validação dos profissionais que ocupam as linhas de frente da educação e lidam com todos os seus desafios. De acordo com Neves e colaboradores (2019) apesar das dificuldades existentes na educação, é possível construir atividades práticas bem planejadas e, considerando as experiências dos docentes, produzir uma aprendizagem relevante para os estudantes. 
Figura 16 - Avaliação da utilidade da sequência didática.

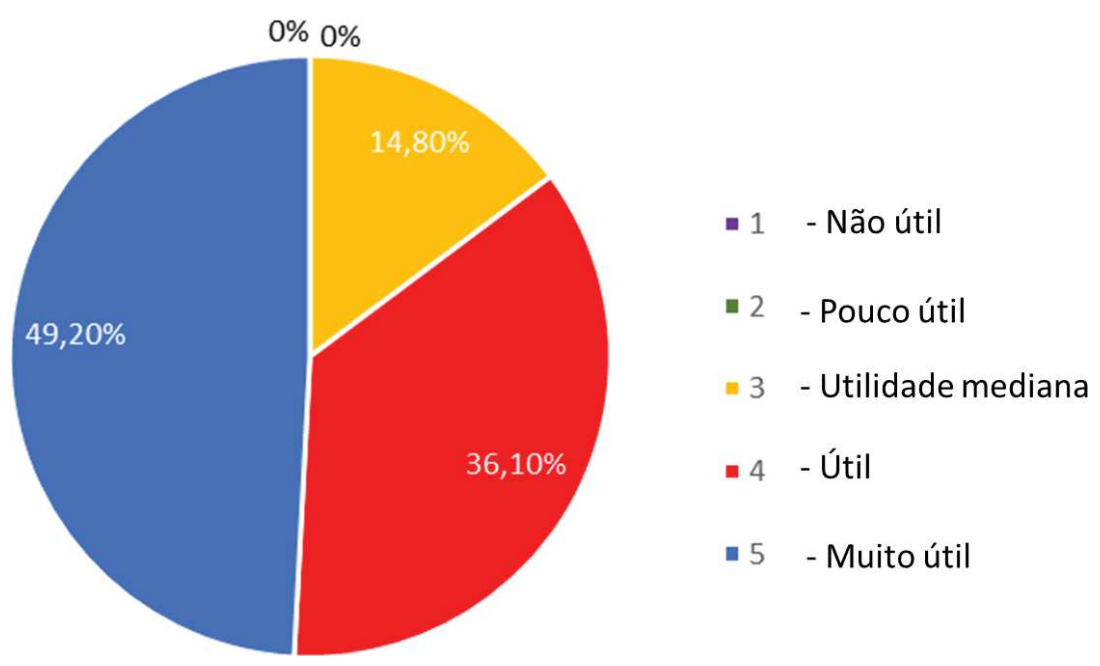

Fonte: Próprio autor elaborado com Google forms (2021).

Como última atividade do questionário, foi criado um espaço para que os partícipes expusessem suas sugestões e críticas ao trabalho e uma crítica bastante mencionada foi a carência de espaço físico, como laboratórios, e de microscópio para essas práticas. No entanto, estes são problemas que podem ser contornados como expressa um dos participantes da pesquisa: “A atividade envolve plantas de fácil aquisição e a metodologia é aplicável. A dificuldade é a falta de microscópio e local adequado, mas é facilmente adaptável”.

Quanto ao espaço, não há necessidade de ser em um laboratório, essas práticas podem ser feitas em sala mesmo, em áreas abertas da escola ou até mesmo em corredores. Já em relação ao microscópio, existem opções variadas como o uso de câmera USB, de câmera do celular e de imagens representando os órgãos vegetais. De acordo com Queiroz e colaboradores (2017), o espaço para o desenvolvimento da educação científica depende da criatividade do professor, pois todo e qualquer espaço pode ser utilizado para uma prática educativa de grande relevância, bastando para isso que haja um planejamento criterioso atendendo aos objetivos.

Outra crítica foi a seguinte: "Nessa sequência didática, ao que me parece, o aluno ainda é muito espectador. Ela parte do pressuposto de que o conteúdo, a forma de apresentação e tudo mais que lhe diz respeito, será interessante para os alunos ou poderá lhe atrair a atenção. Mas, isso é extremamente relativo. Pode atingir uma minoria ou até ninguém. Como a maioria das atividades e planos de aula propostos pelos professores, essa sequência aparenta ter sido construída bem longe dos alunos, com uma visão romântica de que, se o 
professor acha legal e constrói com carinho, vai dar certo. Por que não abre espaço para a construção em grupo? Para o real protagonismo dos alunos? Traz a ideia, pesa, pondera, veja o que eles sabem, o que eles têm a dizer, o que eles podem mostrar e como! Isso seria interessante, pelo menos é o que eu tenho procurado!"

O aluno é um espectador quando se mantém sentado em uma carteira apenas recebendo informações, e, no caso deste trabalho, o estudante busca informações, constrói um ambiente para cultivar plantas e cria materiais para estudo, sendo protagonista da educação e não espectador. Essas atividades são práticas e, como tal, são essenciais para fazer do aluno o condutor do processo de ensino-aprendizagem (SANTOS et al., 2018).

Em relação à crítica que aponta essa metodologia como não interessante, é importante destacar que a prática proposta não é um pressuposto e, sim, o resultado de uma revisão bibliográfica séria, com vários artigos que registram que o contato com as plantas e a atividade de construção de materiais estimulam a criatividade e o interesse, facilitando o processo de aprendizagem (CONDE et al., 2014; DUTRA e GÜLLICH, 2016; SANTOS, 2017; GONÇALVES et al., 2018; MELO et al., 2020).

A criação desta metodologia teve início com o levantamento bibliográfico, que foi amplamente estudado para se chegar à estrutura final da sequência didática. Antes da pandemia, a sequência didática foi iniciada e explicada em sala de aula e gerou muito interesse dos discentes, principalmente nas atividades práticas e de criação de materiais. No entanto, a pandemia não permitiu que a aplicação da sequência didática fosse concluída, em virtude da suspensão das aulas presenciais, fato que resultou na produção deste trabalho e em sua validação pelos professores de Biologia do Ensino Médio. Sendo assim, não se construiu uma proposta longe dos alunos e sim com base na vivência em sala de aula. $O$ desenvolvimento dos saberes profissionais ocorre por meio da experiência de vida, da experiência profissional, afetiva, cultural, social e não só a partir de sua formação acadêmica (GIROTTO JUNIOR et al., 2019).

A maioria dos participantes fez reflexões e elogios parecidos, esses são alguns deles:

"Achei a proposta incrível, a abordagem e a forma como foi montada me surpreendeu, creio que esse trabalho vem de encontro a algumas dúvidas e necessidades dos docentes de como despertar os alunos, e dos discentes a ter aulas mais interativas, onde eles possam fazer parte desta produção do conhecimento adquirido. Parabéns."

"Gostei muito da sequência didática pois é bem objetiva e rica em conteúdo."

"Só parabenizar pela escolha do tema. Entendo ser de grande valia." 
"Parabéns pelo trabalho! Desenvolver atividades de botânica é um grande desafio, é muito bom ter materiais que contem com metodologias ativas para replicação!"

"Adorei a sugestão de trabalho com plantas medicinais, permitindo aos alunos aprenderem de forma científica."

Sabendo que 47 participantes deixaram sugestões e, ou, críticas positivas e que 14 criticaram negativamente o trabalho, foi possível concluir que houve uma aprovação da proposta de mais de $75 \%$ dos participantes, isso mostra que a sequência didática tem grande potencial para conseguir um ensino significativo, atraindo os olhares para a área da Botânica. 


\section{CONCLUSÃO}

Os resultados obtidos junto aos professores de Ensino Médio participantes da pesquisa indicam que esta sequência didática foi aprovada como um ótimo recurso apresentando grande utilidade, facilidade de molde para se adequar às várias realidades escolares existentes no país e apresentando incentivo ao protagonismo dos estudantes.

Com este trabalho, os estudantes poderão compreender quão importantes as plantas são para a natureza, para a sociedade, permitindo assim uma nova visão dos vegetais. Além disso, eles compreenderão a relação entre os seres e a sociedade e a importância de ser um cidadão responsável por suas próprias ações.

É fato que alguns estudantes são mais difíceis de terem a atenção e o interesse conquistados, por isso a intervenção apresenta atividades diversificadas, como trabalhos práticos de cultivo, de construção de materiais para estudo e de modelos de tecidos vegetais com massa de modelar. Desta forma, todos podem construir seus conhecimentos.

Vale ressaltar que as dificuldades são imprescindíveis para que novas abordagens e até novos estudos sejam desenvolvidos para a educação melhorar cada vez mais, em um contexto geral. Por fim esta metodologia, validada por profissionais da educação, se apresenta como excelente opção à aprendizagem, fazendo dela uma aliada para a Botânica, para os professores e para a educação. 


\section{REFERÊNCIAS}

ABDEL-MOGIB, M; ALBAR, H.A.; BATTERJEE, S.M. Chemistry of the genus Plectranthus. Molecules, Arábia Saudita, v.7, n.1, p.271-301, 2002.

ALBUQUERQUE, Roberto L. de et al. Diterpenos tipo abietano isolados de Plectranthus barbatus Andrews. Quím. Nova, São Paulo, v. 30, n. 8, p. 1882-1886, 2007

ALEXIADES, Miguel N. Collecting Ethnobotanical Data: An Introduction to Basic Concepts and Techniques. Institute of Economic Botany, the New York Botanical Garden, 1996.

ANJOS, Cassiane Barroso dos; MOURA, Osvanda Silva de; BIGIO, Narcísio Costa. A Percepção Do Ensino De Botânica No Ensino Médio. REH- Revista Educação e Humanidades. Amazonas. Vol. II, número 2, pág. 609-631, 2021.

ARAÚJO, Denise Lino de. O que é (e como faz) sequência didática? Entrepalavras, Fortaleza - ano 3, v.3, n.1, p. 322-334, 2013.

ARAÚJO, Naiara Pereira de. Construção De Exsicatas Como Recurso Didático: Contribuições Para Uma Aprendizagem Significativa De Botânica Em Tempos De Ensino Remoto Emergencial. VII Congresso Nacional de Educação - Conedu. Maceió, Alagoas, 2020.

BACK, Amanda Knob. Aliando A Aprendizagem De Conceitos Com A Construção De Modelos Didáticos Em Aulas De Anatomia Vegetal. Ciclos Formativos em Ensino de Ciências, Santa Catarina, vol. 2, n. 3, 2019.

BARBOSA, Maria da Conceição Pereira; SANTOS, Josivan Washington M. dos; SILVA, Flávia Carolina Lins da; GUILHERME, Betânia Cristina. O Ensino De Botânica Por Meio De Sequência Didática: Uma Experiência No Ensino De Ciências Com Aulas Práticas. Brazilian Journal of Development, Curitiba, v. 6, n. 7, p. 45105-45122, 2020. 
BARBOSA, Percia Paiva; MACEDO, Mariana; KATON, Geisly França; URSI, Suzana. Preservação E Conservação Da Vegetação Brasileira: Entrelaces Com A Formação Docente E O Ensino De Botânica. Revista Pesquisa Em Foco, São Luís, v. 25, n. 1, 2020.

BATISTA, Leandro Nogueira; ARAÚJO, Joeliza Nunes. A Botânica Sob O Olhar Dos Alunos Do Ensino Médio. Rev. ARETÉ, Manaus, v.8, n.15, p.109-120, 2015.

BATISTONE E SILVA; Maria, TRIVELATO; Silvia Luiza Frateschi. A Mobilização Do Conhecimento Teórico E Empírico Na Produção De Explicações E Argumentos Numa Atividade Investigativa De Biologia. Investigação em Ensino de Ciências, São Paulo, v22 (2), pp. $139-153,2017$.

BERNARDINO, Marjorie Cristina da Cruz; LIMA, Paula Ferreira de; ALMEIDA, Caroline Lessa de; FRANCO, Francisco Carlos. A etnobotânica nos valores culturais e sua Influência na formação do "ser regional". Revista Diálogos Interdisciplinares, São Paulo, v. 8, n 3 ISSN 2317-3793, 2019.

BILL LAWS. 50 Plantas que Mudaram o Rumo da História. Sextante, Rio de Janeiro, 2013.

BRASIL. Lei de Diretrizes e Bases da Educação, n. 9.394. Brasília, 1996.

BRASIL, Ministério da Educação. Secretaria de Educação Média e Tecnológica. Parâmetros Curriculares Nacionais para o Ensino Médio (PCNEM), Ciências da Natureza, Matemática e suas Tecnologias. Brasília, 2000.

BRASIL. MINISTÉRIO DA SAÚDE. SECRETARIA DE ATENÇÃO À SAÚDE. DEPARTAMENTO DE ATENÇÃO BÁSICA. Práticas integrativas e complementares: plantas medicinais e fitoterapia na Atenção Básica/Ministério da Saúde. Secretaria de Atenção à Saúde. Departamento de Atenção Básica, Ministério da Saúde. Brasília, 2012. 
CACCIA-BAVA, Maria do Carmo Gullaci Guimarães; BERTONI, Bianca Waléria; PEREIRA, Ana Maria Soares; MARTINEZ, Edson Zangiacomi. Disponibilidade de medicamentos fitoterápicos e plantas medicinais nas unidades de atenção básica do Estado de São Paulo: resultados do Programa Nacional de Melhoria do Acesso e da Qualidade da Atenção Básica (PMAQ). Ciência \& Saúde Coletiva, São Paulo, 22(5):1651-1659, 2017.

CACHAPUZ, António; PRAIA, João; JORGE, Manuela. Da educação em ciência às orientações para o ensino das ciências: um repensar epistemológico. Ciênc. educ. (Bauru), Bauru, v. 10, n. 3, p. 363-381, 2004.

CAVALCANTE; Valmir Rocha, LEMOS; Alba de Oliveira, TAVARES; Carla Valéria Ferreira, SILVA; Adamares Marques da. O Processo Investigativo No Ensino De Ciências Como Promotor Da Articulação Teoria-prática Em Atividade Experimental De Cromatografia Com Alunos Do Ensino Fundamental II Formação De Professores À Distância E Inovação Das Práticas Educativas. Anais CIET: EnPED - Educação e Tecnologias: Aprendizagem e construção do conhecimento, Pernambuco, 2018.

COMposta são PaUlo. Cartilha Para Plantio De Pequenos Jardins Urbanos. São Paulo, BRASIL - 2014.

CONDE, Bruno Esteves; MARTINS, Andréa Esteves; FONSECA, Amanda Surerus. Ferramentas da etnofarmacologia no ambiente escolar: potencial para a educação ambiental? Revbea, São Paulo, V. 9, N. 1, p. 116-131, 2014.

CORTE, Viviana Borges; SARAIVA, Fernanda Guimarães; PERIN, Idalina Tereza de Almeida Leite. Modelos Didáticos Como Estratégia Investigativa E Colaborativa Para O Ensino De Botânica. Revista pedagógica. v.20, n.44, 2018.

COSTA, Emanuelle Almeida da; OLIVEIRA, Isabel Vitória Gonzaga de; SANTOS, Ana Carolina Gonçalves dos; PINTO, Andréa Vasconcelos Freitas; MATOS, Elaine Cristine do Amarante; PRATA, Ana Paula do Nascimento; CUNHA, Marlécio Maknamara da Silva. Percepção De Professores Sobre A Disciplina Botânica Geral No Ensino Superior Alagoano. Revista Insignare Scientia - RIS, Alagoas, v. 2, n. 4, p. 278-296, 2019. 
CRETTON, Sylvian et al. Anti-inflammatory and antiproliferative diterpenoids from Plectranthus scutellarioides. Phytochemistry. Suíça, V. 154, n. 39-46, 2018.

CUNHA, A. P. Aspectos históricos sobre plantas medicinais, seus constituintes ativos e fitoterapia. Plantas e produtos vegetais em fitoterapia. Fundação Calouste Gulbenkian, Lisboa, 2003.

DOURADO, Diego Augusto Oliveira; ALMEIDA, Cecília de Fátima Castelo Branco Rangel de. Alfabetização e Iniciação Científica na Escola: Conceitos e Perspectivas nas Áreas de Botânica no Ensino Médio. Diversitas Journal. Santana do Ipanema/AL. vol. 6, n. 1, p.1318$1345,2021$.

DUTRA, Ana Paula; GÜLliCH, Roque Ismael da Costa. Ensino De Botânica: Metodologias, Concepções De Ensino E Currículo. Ensino de Ciências e Tecnologia em Revista. Rio Grande do Sul. Vol. 6, n. 2. 2016.

EMATER-PARÁ, GOVERNO DO PARÁ. Cartilha de Horta para Ambiente Residencial. Belém do Pará. 2020.

FARIA, Juliana Luna Moreira de; ALBUQUERQUE, Ulysses Paulino de. Como Fatores Socioeconômicos Podem Afetar O Conhecimento De Plantas Medicinais? Revista Brasileira de Meio Ambiente, Pernambuco, v.3, n.1, 033-036, 2018.

FEIFFER, Allyson Henrique Souza; MIOTTO, Haline da Silva; GONÇALVES, Raul Calixto; BENITES, Leonardo Barboza; DINARDI, Ailton Jesus. Aprendizagem De Botânica A Partir Do Levantamento De Plantas Herbáceas Do Parque Estadual Do Espinilho. Anais do 10 Salão Internacional De Ensino, Pesquisa E Extensão - SIEPE, Universidade Federal do Pampa, Rio Grande do Sul, 2019.

FERNANDES; Viviane Carvalho, SILVA; Wildma Mesquita. Metodologias De Aprendizagem No Processo De Formação Pedagógica Continuada De Professores Universitários. III congresso de inovação e metodologias no ensino superior, I encontro das licenciaturas, Rio de Janeiro, 2017. 
FONSECA, Liliane Ramos da; RAMOS, Paula. Ensino De Botânica Na Licenciatura Em Ciências Biológicas De Uma Universidade Pública Do Rio De Janeiro: Contribuições Dos Professores Do Ensino Superior. Revista Ensaio, Belo Horizonte, v.20, e11387, 2018.

GirotTo JÚNiOR, G.; DE PAUlA, M. A.; MATAZO, D. R. C. Análise De Conhecimento Sobre Estratégias De Ensino De Futuros Professores De Química: Vivência Como Aluno E Reflexão Como Professor. GÓNDOLA, ENSEÑANZA Y APRENDIZAJE DE LAS CIENCIAS. Espanha. Vol. 14, n 1, pp. 35-50, 2019.

GONSALVES, Flávio Nóbrega; FARIAS, Alex Bruno da Silva; QUEIROZ, Rubens. O Estudo de Plantas Medicinais na Melhoria da Aprendizagem dos Conteúdos de Botânica no Ensino Médio. Anais - V CONEDU. Paraíba. 2018.

ITO, Takuya et al. Three New Abietane-Type Diterpenoids From The Leaves Of Indonesian Plectranthus scutellarioides. Fitoterapia, Japão, 127, 146-150, 2018.

JACOBUCCI, Daniela Franco Carvalho. Contribuições Dos Espaços Não Formais De Educação Para A Formação Da Cultura Científica. Em extensão, Uberlândia, v.7, 2008.

KOVALSKI, Mara Luciane; OBARA, Ana Tiyomi. O estudo da etnobotânica das plantas medicinais na escola. Ciênc. educ. (Bauru), Bauru, v. 19, n. 4, p. 911-927, 2013.

LEVITA et al. Pharmacological Activities of Plectranthus scutellarioides (L.) R.Br. Leaves Extract on Cyclooxygenase and Xanthine Oxidase Enzymes. Journal of Medicinal Plants Research. Indonesia, Vol. 10(20), pp. 261-269, 2016.

LOPES, F.; BetTencourt, T. O Ensino Da Biologia Numa Perspectiva Por Pesquisa: Contributos De Uma Investigação Preliminar No Ensino Secundário. Enseñanza de lãs Ciencias, Barcelona, p. 508-511, 2009.

LORENZI, H.; MATOS, F.J.A. Plantas Medicinais no Brasil. Nativas e Exóticas. 2a ed. Instituto Plantarum, Nova Odessa. São Paulo. P. 543, 2008. 
LUKHOBA, C.W.; SIMMONDS, M.S.J.; PATON, A.J. Plectranthus: A Review Of Ethnobotanical Uses. Journal of Ethnopharmacolgy, Quênia, v.103, n.1, p.1-24, 2006.

MACEDO, Marina; URSI, Suzana. Botânica Na Escola: Uma Proposta Para O Ensino De Histologia Vegetal. Revista da SBEnbio, São Paulo, n. 9, p. 2723-2733, 2016.

MACIEL, M. A. M.; CORTEZ, J. K. P. C.; GOMES, F. E. S. O gênero croton e aspectos Relevantes de diterpenos clerodanos. Revista Fitos, Rio Grande do Norte, Vol. 2, Nº 03. 2006.

MARINHO, Julio Cesar Bresolin et al. A Botânica Na Escola: Apresentando Possibilidades De Trabalho Com Alunos Cegos E Visuais E Aproximando A Universidade Da Escola De Educação Básica. Extensão em Foco, Rio Grande do Sul, [S.1.], n. 12, 2016.

MELO, Dayanne Lima de; SILVA, Maria Laura da; SILVA, Mirelle Pereira da Silva; SILVA, Flávia Carolina Lins da; FARIAS FILHO, Everaldo Nunes de; GUILHERME, Betânia Cristina. Dissecação de flores como ferramenta de ensino de Botânica no Ensino Médio. Braz. J. of Develop. Curitiba, vol. 6, n. 10, p. 78799-78810, 2020.

MELO, E.A., ABREU, F.F., ANDRADE, A.B., ARAÚJO, M.I.O. A Aprendizagem De Botânica No Ensino Fundamental: Dificuldades E Desafios. Scientia Plena, Sergipe, 8: 1-7. 2012

MENG, L et al. Effects Of Drought Stress On Fluorescence Characteristics Of Photosystem Ii In Leaves Of Plectranthus Scutellarioides. Photosynthetica. China, 54, 414-421, 2016.

MIQUELANTE, Marileuza Ascencio; PONTARA, Claudia Lopes; CRISTOVÃO, Vera Lúcia Lopes; SILVA, Rosinalva Ordonia da. As modalidades da avaliação e as etapas da Sequência didática: articulações possíveis. Trab. Ling. Aplic., Campinas, n (56.1), p. 259$299,2017$.

MOREIRA, Luiz Henrique Liberato; FEITOSA, Antônia Arisdélia Fonseca Matias Aguiar; QUEIROZ, Rubens Teixeira de. Estratégias Pedagógicas Para O Ensino De Botânica Na Educação Básica. Experiências em Ensino de Ciências. Paraíba, V.14, No.2, 2019. 
MUKHERJEE, S., GHOSH, B., SUMITA, J. Establishment Of Forskolin Yielding Transformed Cell Suspension Cultures Of Coleus Forskohlii As Controlled By Different Factors. Journal of Biotechnology. India, 76, 73-81. 2000.

NAGASAWA, Débora; WUO, Moacir; MATSUO, Patrícia M.; AMARAL, Tatiana Platzer do; SCABBIA, Renata J. Almeida. Educação Ambiental E Botânica No Ensino Médio: Estudo De Arbustos E Árvores Do Pátio Da Escola. Revista Humanidades e Inovação. São Paulo, v.8, n.5, 2020.

NERIS, D. A Importância Das Aulas Práticas No Ensino De Botânica. Disponível em: http://biopedagogia.webnode.com.br/news/a-import\%C3\%A2ncia-de-aulas-praticas--noensino-de-bot\%C3\%A2nica/, (acessado em fevereiro de 2019), 2013.

NEVES, Amanda; BÜNDCHEN, Márcia e LISBOA, Cassiano Pamplona. Cegueira Botânica: é possível superá-la a partir da educação? Ciência e Educação, Rio Grande do Sul, v. 25, n. 3, p. 745-762, 2019.

OMS, 2001 WORLD HEALTH ORGANIZATION. Legal Status of Tradicional Medicine and Complementary/Alternative Medicine: A Worldwide Review; 2001.

PORTELINHA, Márcia Kaster; BARBIERI, Rosa Lía; HECK, Rita Maria; LIMA, Ângela Roberta Alves; LOPES, Caroline Vasconcellos. Reinterpretando As Plantas Medicinais A Partir Do Referencial Yin-Yang Da Medicina Tradicional Chinesa. Journal of Nursing and Health, Rio Grande do Sul, 7(3), e 177310, 2017.

RIBEIRO, Fabiane Fonseca; AOYAMA, Elisa Mitsuko; TEIXEIRA, Marcos da Cunha; MENEZES, Luis Fernando Tavares de. A Universidade como espaço complementar ao Ensino de Botânica no Ensino Médio. Kiri-Kerê - Pesquisa em Ensino. São Mateus Espirito Santo. v. 1, n. 9. 2020.

RODRIGUES, T.S. et al. Métodos de secagem e rendimento dos extratos de folhas de Plectranthus barbatus (boldo-daterra) e P. ornatus (boldo-miúdo). Revista brasileira de plantas medcinais, Botucatu, v. 13, n. spe, p. 587-590, 2011. 
SALATINO, Antonio; BUCKERIDGE, Marcos. "Mas de que te serve saber botânica?". Estud. av., São Paulo, v. 30, n. 87, p. 177-196, 2016.

SANTOS, Fernando Santiago dos. Ensino E Aprendizagem de Botânica Por Meio De Investigação Por Pesquisa E Produção Colaborativa De Material Didático. XI Encontro Nacional de Pesquisa em Educação em Ciências - XI ENPEC. Florianópolis, SC. 2017

SANTOS, Jamille Jesus dos; BARBOSA, Renata Larissa dos Santos; BITTENCOUR, Irleide; MADEIRA, Ana Verena. O Protagonismo Estudantil Na Construção Do Conhecimento Em Turmas Do Ensino Médio De Um Colégio Público De Salvador - Ba. VII ENALIC. Fortaleza, CE. 2018.

SANTOS-LIMA, T.M.; SANTOS, D.R.V.; SOUZA, R.M.; BASTOS, N.G.; VANNIERSANTOS, M.A.; NUNES, E.S.; DIAS-LIMA, A.G. Plantas Medicinais Com Ação Antiparasitária: Conhecimento Tradicional Na Etnia Kantaruré, Aldeia Baixa Das Pedras, Bahia, Brasil. Rev. Bras. Pl. Med., Campinas, v.18, n.1, supl. I, p.240-247, 2016.

SENICIATO, Tatiana; CAVASSAN, Osmar. Aulas De Campo Em Ambientes Naturais E Aprendizagem Em Ciências: Um Estudo Com Alunos Do Ensino Fundamental. Ciênc. educ. (Bauru), Bauru, v. 10, n. 1, p. 133-147, 2004.

SILVA, João Rodrigo Santos da; GUIMARÃES, Fernando; SANO, Paulo Takeo. Teaching Of Botany In Higher Education: Representations And Discussions Of Undergraduate Students. Revista Electrónica de Enseñanza de las Ciencias, São Paulo, Vol. 15, № 3, 380$393,2016$.

SILVA, José Joedson Lima; CAVALCANTE, Francisco Lucas Pacheco; XAVIER, Vinicius Facundo; GOUVEIA, Luciana De Freitas Patriota. Produção De Exsicatas Como Auxílio Para O Ensino De Botânica Na Escola. Conex. Ci. e Tecnol. Fortaleza/CE, v. 13, n. 1, p. 30 - 37 , 2019. 
SOUSA; Antônio Francisco de. Experiência Do Ensino De Biologia Pela Experimentação Em Uma Escola Estadual De Educação Profissional. Essentia. Sobral, v. 20, n. 2, p. 9-14, 2019.

SOUSA, Rodrigo Francisco de; OLIVEIRA, Ykaro Richard; ABREU, Maria Carolina de. As Coleções Botânicas Sob A Perspectiva De Alunos Da Educação Básica. Biota Amazônia Open Jouranl System. Piauí, V 9, n 4, p 33 - 36, 2020.

SULZBACH, Angelica; JOHANN, Liana. Avaliação Do Uso Do Museu De Ciências Univates Como Espaço Não Formal De Ensino Por Professores De Escolas Públicas E Particulares. Revbea, São Paulo, v.16, N. 1, p. 19-32, 2021.

TOMAZZONI, Marisa Ines; NEGRELlE, Raquel Rejane Bonato; CENTA, Maria de Lourdes. Fitoterapia Popular: A Busca Instrumental Enquanto Prática Terapêutica. Texto \& Contexto Enfermagem. Santa Catarina, vol. 15, n. 1, p. 115-121, 2006.

TOWATA, N. et al. Análise Da Percepção Dos Licenciandos Sobre O "Ensino De Botânica Da Educação Básica”. Revista da SBenBio, São Paulo, v.3, p.1603-12, 2010.

URSI, Suzana.; BARBOSA, Pércia Paiva; SANO, Paulo Takeo; BERSHEZ, Flávio Augusto de Souza. Ensino De Botânica: Conhecimento E Encantamento Na Educação Científica. Estudos Avançados, São Paulo, n.84, v.32, SP, P. 0-24, 2018.

VEIGA JUNIOR, Valdir F.; PINTO, Angelo C. Plantas Medicinais: Cura Segura? Quim. Nova, Rio de Janeiro, Vol. 28, No. 3, 519-528, 2005.

WANDERSEE, J. H.; SCHUSSlER, E. E. Toward A Theory Of Plantblindness. Plant Science Bulletin, Ohio, v.47, p.2-9, 2002. 


\section{APÊNDICE A - Questionário para estudantes}

1) Você gosta do conteúdo de Biologia?

( ) Sim.

( ) Não.

( ) Não conheço.

2) Você sabe o que é botânica?

( ) $\operatorname{Sim}$

( ) Sim, mas não me interesso

( ) Não

3) O que você acha das plantas?

4) Qual a relação da sua família com as plantas?

( ) Temos plantas em casa e ajudo a cuidar

( ) Temos plantas em casa, mas nunca me preocupei com elas

( ) Não temos plantas em casa, mas gostaria de ter

( ) Não temos plantas em casa e não me importo com isso

5) Você já estudou sobre as plantas?

( ) Sim, gosto muito

( ) Sim, mas não gostei do assunto

( ) Não, mas gostaria de estudar

( ) Não, esse assunto não parece interessante

6) Se você já estudou sobre as plantas, diga o que achou desse estudo?

7) Qual a importância você acha que as plantas têm na natureza? 
8) O que você sabe sobre Anatomia Vegetal? 


\section{APÊNDICE B - Questionário para professores}

1. Como você avalia a sequência didática "Plantas Medicinais na Aprendizagem de Botânica do Ensino Médio" no que diz respeito ao tema, objetivo, conteúdo, tempo de aplicação e avaliação? Se quiser comentar sua resposta, a última questão traz um campo de texto em que você pode detalhar sua opinião.
( ) Ótima
( ) Boa
( ) Regular
( ) Ruim
( ) Péssima

2. Você considera a sequência didática "Plantas Medicinais na Aprendizagem de Botânica do Ensino Médio" aplicável em suas aulas?
( ) $\mathrm{Sim}$
( ) Somente parte dela
( ) não

3. Você faz uso de procedimentos práticos em suas atividades didáticas?
( ) Uso sempre
( ) Uso frequentemente
( ) Uso esporadicamente
( ) Uso raramente
( ) Não uso

4. Se você não utiliza procedimentos práticos, indique o(s) motivo(s). Você pode marcar mais de uma alternativa nesta questão.
( ) Falta de preparo das atividades
( ) Poucos tempos de aula
( ) Falta de espaço físico para as práticas
( ) Excesso de conteúdo a ser ensinado em pouco tempo

5. Se você utiliza procedimentos práticos avalie sua experiência.
( ) Ótima
( ) Boa
( ) Regular
( ) Ruim
( ) Péssima

6. Sobre a metodologia apresentada, você considera possível reproduzi-la?
( ) Sim, totalmente
( ) Sim, em parte
( ) Não

7. Sobre o cultivo das plantas e a confecção de lâminas histológicas, você considera que a atividade incentivaria o protagonismo dos seus alunos? 

( ) $\operatorname{Sim}$
( ) Sim para a maioria
( ) Não para a maioria
( ) não

8. Considerando a sua realidade de trabalho e aplicando uma escala de 1 para não útil a 5 para muito útil, que nota você daria para a sequência didática?
( ) 1
( ) 2
( ) 3
( ) 4
( ) 5

9. Utilize este espaço para apresentar suas sugestões e críticas para a melhoria deste trabalho. Se desejar, detalhe respostas indicadas anteriormente. 

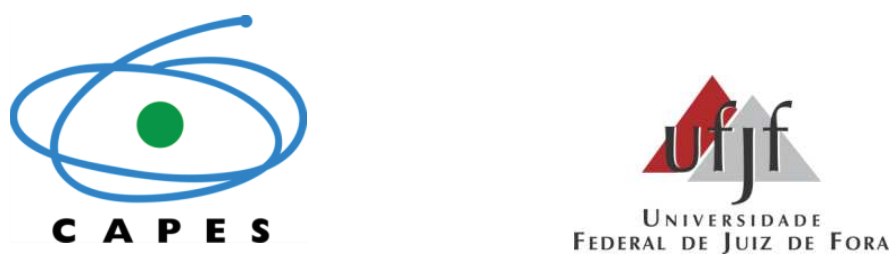

PRODUTO: SEQUÊNCIA DIDÁTICA

\title{
Plantas Medicinais na Aprendizagem de Botânica do Ensino Médio
}

\author{
Roberto Cézar Tavela \\ Mestrando em Ensino de Biologia - PROFBIO - UFJF/JF \\ Professor da rede pública estadual do Rio de Janeiro.
}

O presente trabalho foi realizado com o apoio da Coordenação de Aperfeiçoamento de Pessoal de Nível Superior - Brasil (CAPES) - Código de Financiamento 001.

Juiz de Fora 


\section{Apresentação}

Esta sequência didática apresenta uma sucessão de atividades a serem desenvolvidas com alunos, as quais contam com pesquisas, formulação de hipóteses, aulas remotas e aulas prática s, com o objetivo de tornar a Botânica um componente agradável e interessante aos alunos envolvidos no processo ensino-aprendizagem.

\section{Introdução}

A educação é um processo de facilitação da aprendizagem, de aquisição de hábitos e valores que irão formar um cidadão. Apesar da Botânica ser vista como um conteúdo difícil, desanimador e descontextualizado, ela também tem esse papel de formar um cidadã o que sabe das suas origens e que reconhece a importâncias dos demais seres vivos, cada qual com suas especificidades.

A Botânica tem sido considerada como um componente árido, entediante e desanimador do currículo escolar por parte dos estudantes e da $\mathrm{s}$ pessoas que já o estudaram (SILVA et al, 2019). Aparentemente, o ser humano não é capaz de perceber a presença das plantas em meio aos demais seres vivos ( NEVES et al, 2019 ). Mesmo fora da s escolas, os vegetais são reconhecidos como meros figurantes de um plano de fundo de to nalidade verde, caracterizando o que Wandersee e Schu ssler (2002) denominaram de " cegueira vegetal". Ainda, de acordo com estes pesquisa dores, as pla ntas seria $\mathrm{m}$ ignoradas devido à neurofisiologia, qu e é o estudo da $\mathrm{s}$ funções e do funciona mento do sistema nervoso dos seres vivos, o qual não permite que o cérebro humano perceba seres estáticos e que não representam perigo.

De acordo com a revisão bibliográfica realizada sobre o ensino de botânica, foi observado que alguma s dificuldades ( Tabela 1 ) no ensino aprendizagem são recorrentes e estão relacionadas direta mente com a cegueira botânica ( NEVES et al., 2019 ; COSTA et al, 2019 ), apesar de esta ser citada menos vezes. 
Tabela 1 - Categorias de dificuldades do ensino de botânica

\begin{tabular}{|c|l|}
\hline \multicolumn{2}{|c|}{ Categorias de dificuldades do ensino de botânica } \\
\hline 1 & Desinteresse do aluno \\
\hline 2 & Desinteresse do professor \\
\hline 3 & Falta de atividades práticas \\
\hline 4 & Falta contextualização \\
\hline 5 & Cegueira botânica \\
\hline
\end{tabular}

Fonte: Próprio autor (2020). Categorização das dificuldades encontradas na revisão bibliográfica sobre o ensino de botânica.

\section{Justificativa}

Considerando-se os pontos descritos de dificuldades, de possibilidades e a preocupação com o ensino da botânica, como citado por diversos autores como Towata e colaboradores (2010), torna-se oportuno o desenvolvimento de um trabalho utilizando o cultivo de plantas medicinais, sua utilização pela comunidade escolar e sua preparação para atividades práticas, com a finalidade de obter atenção, de aguçar a curiosidade e de permitir o reconhecimento e a aprendizagem da biologia vegetal pelos alunos do ensino médio. Desta forma, é possível mostrar a importância da construção das aulas de acordo com a aprendizagem contextualizada (SENICIATO e CAVASSAN, 2004), que por fim, corrobora com ideias de formação pessoal e social dos alunos (CACHAPUZ, PRAIA e JORGE, 2004; LOPES e BETTENCOURT, 2009).

\section{$1^{\text {a }}$ Etapa - Aplicação de questionário semiestruturado}

\section{Tempo de aplicação: 1 aula}

Esse tipo de questionário apresenta perguntas básicas sobre o tema e permite conseguir informações de uma forma mais livre, sem condicionar a um padrão de alternativas. Assim, tem-se como objetivo apreender o conhecimento prévio dos alunos sobre as plantas. $\mathrm{Na}$ aplicação do questionário o professor deverá deixar claro que não se trata de uma prova ou qualquer ferramenta avaliativa, e que eles podem responder as questões sem preocupação com avaliação. 


\section{$\underline{\text { Modelo do questionário semiestruturado }}$}

1) Você gosta do conteúdo de Biologia?

( ) Sim.

( ) Não.

( ) Não conheço.

2) Você sabe o que é botânica?

( ) $\mathrm{Sim}$

( ) Sim, mas não me interesso

( ) Não

3) O que você acha das plantas?

4) Qual a relação da sua família com as plantas?

( ) Temos plantas em casa e ajudo a cuidar

( ) Temos plantas em casa, mas nunca me preocupei com elas

( ) Não temos plantas em casa, mas gostaria de ter

( ) Não temos plantas em casa e não me importo com isso

5) Você já estudou sobre as plantas?

( ) Sim, gosto muito

( ) Sim, mas não gostei do assunto

( ) Não, mas gostaria de estudar

( ) Não, esse assunto não parece interessante

6) Se você já estudou sobre as plantas, diga o que achou desse estudo?

7) Qual a importância você acha que as plantas têm na natureza?

8) Já ouviu falar em Anatomia Vegetal? 


\section{$2^{\text {a }}$ Etapa - Aula expositiva dialogada.}

\section{Tempo de aplicação: $\underline{\underline{2} \text { aulas }}$}

Durante uma atividade investigativa, o professor proporciona ao aluno se deparar com uma situação-problema que o levará à reflexão, proposição de hipóteses, experimentação, análise de resultados e discussão. Nesse ambiente o aluno adquire de forma gradual a cultura e linguagem científica (SASSERON e CARVALHO, 2011). Com base nesses princípios, nesta aula os estudantes terão a oportunidade de refletir sobre a importância dos vegetais, como estes seres causaram o aumento da quantidade de gás oxigênio disponível na atmosfera, permitindo o aparecimento dos demais seres terrestres. Como as plantas, seres tão estáticos foram capazes de mudar o rumo da história dos seres humanos a partir da capacidade de produzir alimento e assim concentrar uma maior quantidade de pessoas em um determinado local, formando ocasionalmente uma sociedade, cidades, estados e países.

Para uma maior contextualização das espécies escolhida, com fins motivacionais, serão exibidos, áudios elaborados por Sérgio Monteiro, coordenador do projeto Arranjo Produtivo Local de Plantas Medicinais do Palácio Itaboraí - FIOCRUZ Petrópolis, sobre as duas espécies vegetais que foram escolhidas para este trabalho, Plectranthus barbatus Andrews e Plectranthus scutellarioides (L.) R. Br.. Outras espécies podem ser escolhidas, mas a facilidade que essas espécies proporcionam para cortes e visualização devem ser avaliadas.

\section{Plectranthus barbatus Andrews}

Áudio 1: Caracterização da espécie vegetal

Link executável Conteúdo do áudio:

do arquivo de "Essa espécie de boldo ela é um arbusto, ela pode chegar, áudio: bem arriscado, até 5 metros de altura, as folhas são bem pilosas,

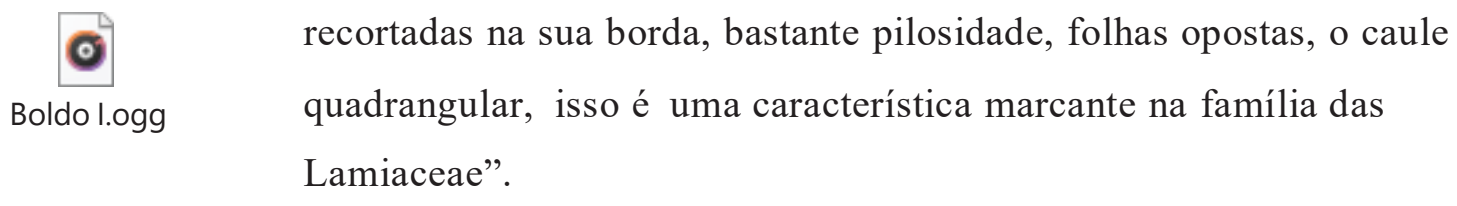

Para exemplificar a caracterização de $P$. barbatus, serão mostradas aos alunos as fotos das Figuras 1 e 2. 
Figura 1: Hábito de Plectranthus barbatus Andrews, boldo, cultivado cultivo no Palácio Itaboraí - FIOCRUZ, Petrópolis, RJ

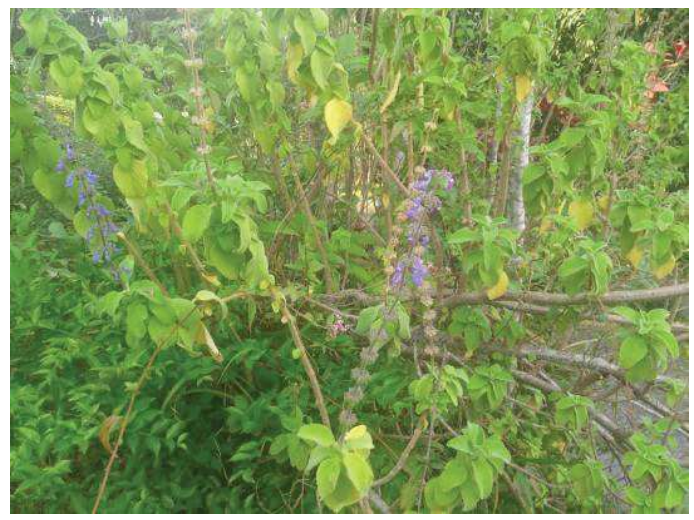

Fonte: Sérgio Monteiro - FIOCRUZ, Petrópolis (2020).

Figura 2: Detalhe das partes vegetativas de Plectranthus barbatus Andrews, boldo, cultivado no Palácio Itaboraí - FIOCRUZ, Petrópolis, RJ.

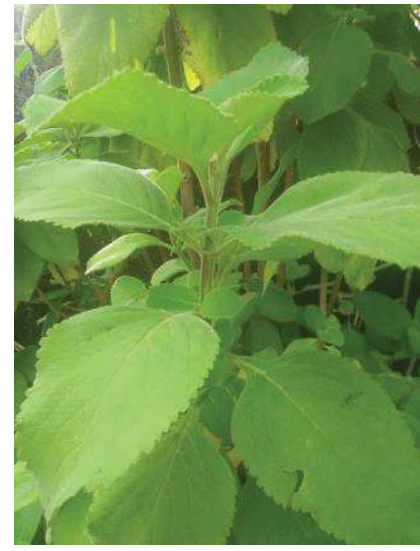

Fonte: Sérgio Monteiro - FIOCRUZ, Petrópolis (2020).

Áudio 2: Método de propagação vegetativa

Link executável Conteúdo do áudio:

do arquivo de "Agora nós vamos ver o método de propagação. A áudio: propagação desta espécie é assexuada, é através de uma estaca, de - um galho, temos que ter pelo menos dois nós que estejam
Boldo ll.ogg enterrados no substrato".

Para exemplificar o método de propagação vegetativa, serão mostradas aos alunos as fotos das Figuras 3 e 4 . 
Figura 3: Estaca de Plectranthus barbatus Andrews, para fins de propagação vegetativa.

Fonte: Sérgio Monteiro - FIOCRUZ, Petrópolis (2020).

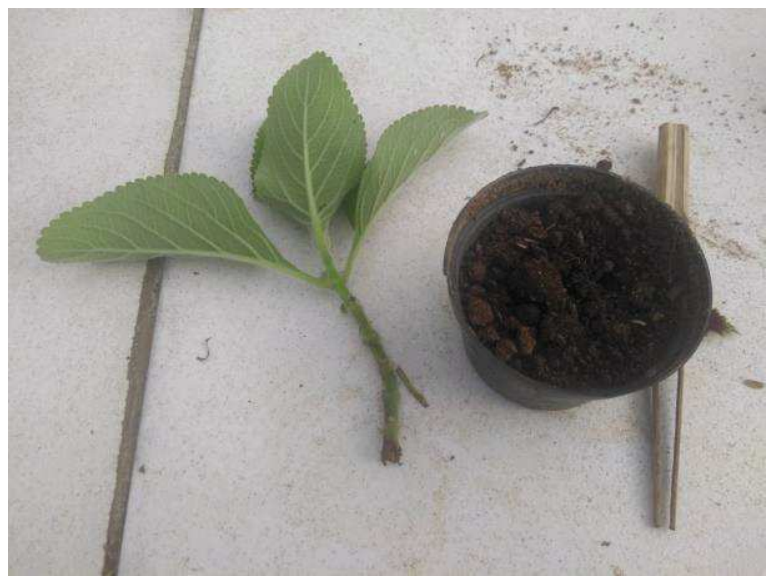

Figura 4: Plantio de estaca de Plectranthus barbatus Andrews, para fins de propagação vegetativa.

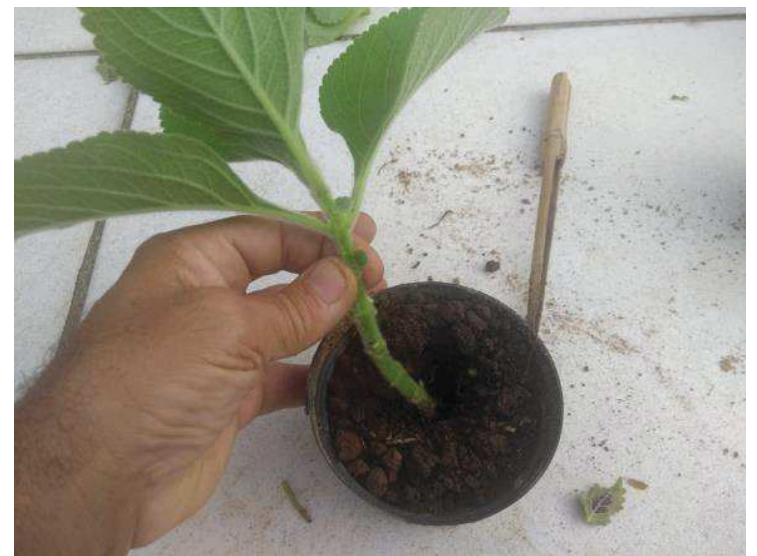

Fonte: Sérgio Monteiro -FIOCRUZ, Petrópolis (2020).

\section{Plectranthus scutellarioides (L.) R. Br.}

Áudio 3: Caracterização da espécie vegetal

Link executável Conteúdo do áudio:

do arquivo de "Essa espécie de coleus é o Plectranthus scutellarioides, ele áudio: é um subarbusto podendo variar sua altura de um metro e um metro

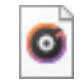

Coleus.ogg e meio e é muito ramificado para as laterais, as folhas têm uma forma de coração, cordiformes, um limbo bem serreado, mais arredondado mas bem marcante, as folhas também são opostas e o caule quadrangular, como foi dito em relação ao P. barbatus, que é uma característica da família das Lamiaceae”. 
Para exemplificar a caracterização de $P$. scutellarioides, serão mostradas aos alunos as fotos das Figuras 5, 6 e 7 e exemplificando a propagação vegetativa na Figura 8.

Figura 5: Hábito do subarbusto Plectranthus scutellarioides (L.) R. Br cultivado no Palácio Itaboraí - FIOCRUZ, Petrópolis, RJ.

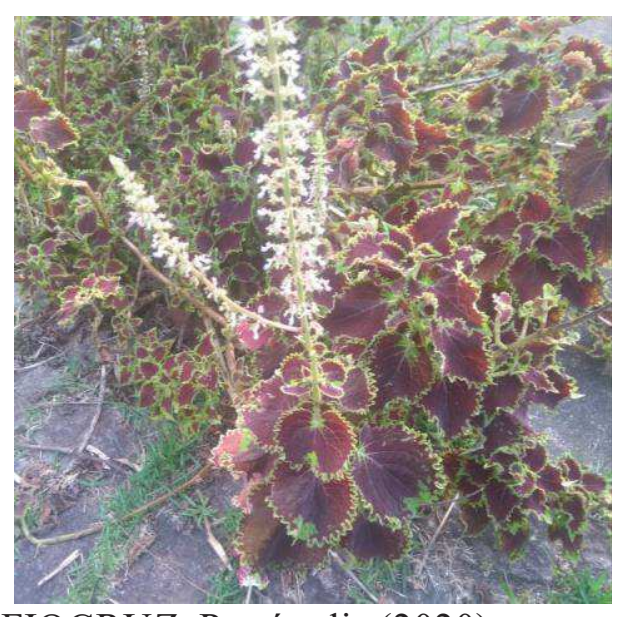

Fonte: Sérgio Monteiro - FIOCRUZ, Petrópolis (2020).

Figura 6: Detalhe das folhas cordiformes de Plectranthus scutellarioides (L.) R. Br. cultivado no Palácio Itaboraí - FIOCRUZ, Petrópolis, RJ.

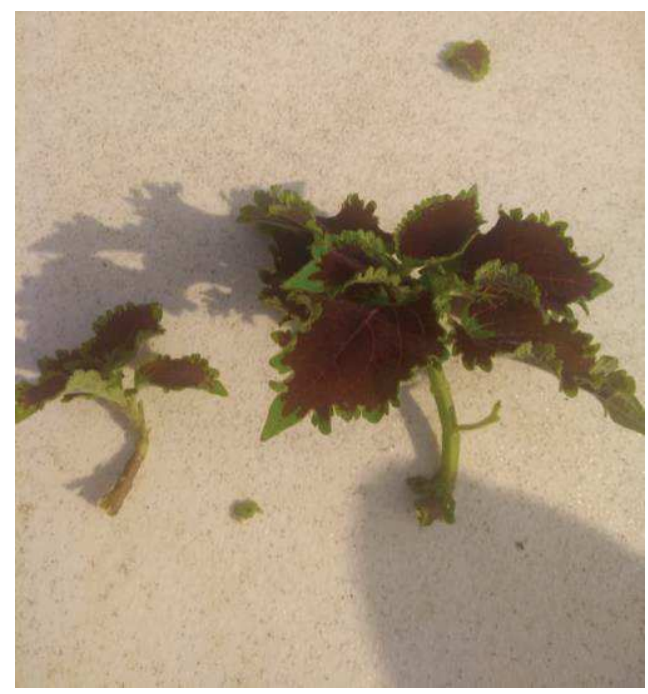

Fonte: Sérgio Monteiro - FIOCRUZ, Petrópolis (2020). 
Figura 7: Detalhe da filotaxia oposta de Plectranthus scutellarioides (L.) R. Br. cultivado no Palácio Itaboraí - FIOCRUZ, Petrópolis, RJ.

Fonte: Sérgio Monteiro - FIOCRUZ, Petrópolis (2020).

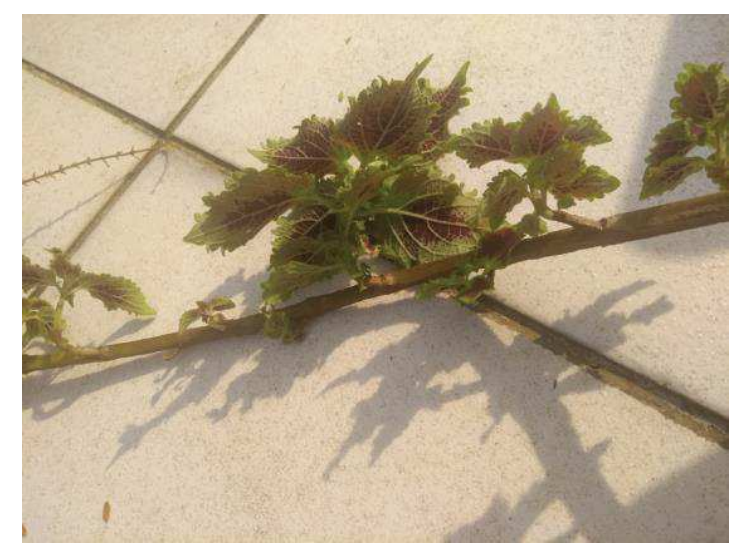

Figura 8: Plantio de estaca de Plectranthus scutellarioides (L.) R. Br, para fins de propagação vegetativa.

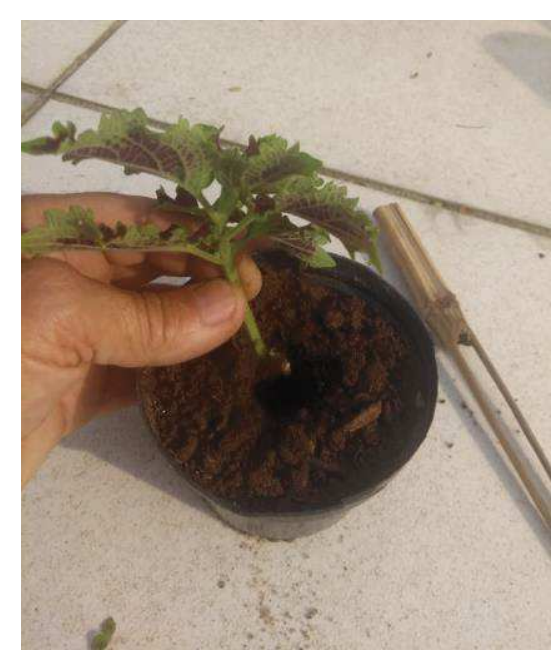

Fonte: Sérgio Monteiro - FIOCRUZ, Petrópolis (2020).

Após ouvir os áudios e ver as fotos, os alunos farão buscas de artigos, usando a internet no laboratório de informática, sobre as duas espécies, Plectranthus barbatus Andrews e Plectranthus scutellarioides (L.) R. Br.. A busca por artigos será realizada pelos sites Scielo e Google Acadêmico. O professor acompanhará toda essa etapa, que terá como objetivo, além da aquisição de informações sobre as espécies selecionadas, entender a importância de se utilizar sites confiáveis na busca de informações científicas e saber diferenciar informações científicas de informações populares. 


\section{$3^{\text {a }}$ Etapa - Experimentação prática - plantio de mudas}

\section{Tempo de aplicação: $\underline{1 \text { aula }}$}

\section{Materiais necessários:}

- Jardineiras - a quantidade irá variar de acordo com o tamanho da turma, o ideal é que todos possam ser responsáveis por ao menos uma muda

- Brita - um saco de brita de aproximadamente $30 \mathrm{~kg}$ é suficiente para três jardineiras, em média

- Areia - um saco de areia de aproximadamente $20 \mathrm{~kg}$ é suficiente para para três jardineiras, em média

- Terra preta - um saco de $5 \mathrm{~kg}$ preenche uma jardineira e meia

- Terra vegetal - um saco de $5 \mathrm{~kg}$ é suficiente para 6 jardineiras

- Mudas de plantas.

Para que os estudantes possam ter contato com as espécies selecionadas será criado, um ambiente de cultivo em que as duas espécies selecionadas para esse trabalho serão plantadas em seis jardineiras de plástico. Toda essa etapa será executada pelos alunos, com supervisão do professor.

Haverá a disponibilização de links com materiais que podem motivar e auxiliar nesta etapa, e que poderão tirar dúvidas no plantio, além das informações fornecidas pelo professor.

- Composta São Paulo -

https://www.google.com/url?sa=t\&rct=j\&q=\&esrc=s\&source=web\&cd=\&ved=2ahU

KEwi1-

6velcPrAhUBHbkGHZ7_D7MQFjAAegQIAxAB\&url=http\%3A\%2F\%2Fecosredenutri.bvs.br\%2Ftikidownload_file.php\%3FfileId\%3D886\&usg=AOvVaw1Bq805oV1AA9VSkJ1GO0dJ

- EMATER-PARÁ

https://agenciapara.com.br/midias/anexos/18700A_cultivo_de_horta_versao_final.pdf

Montagem da jardineira:

O fundo das jardineiras deve ser preenchido com pedras, as quais são importantes para uma boa drenagem da água e sustentação do solo. Em seguida, deve-se colocar areia até 
cobrir as pedras, esta ajudará também na drenagem da água e poderá fornecer alguns nutrientes minerais às plantas (Figura 11).

Figura 11: Exemplo de preenchimento das jardineiras com brita, areia e terra, para fornecer substrato adequado ao cultivo das mudas.

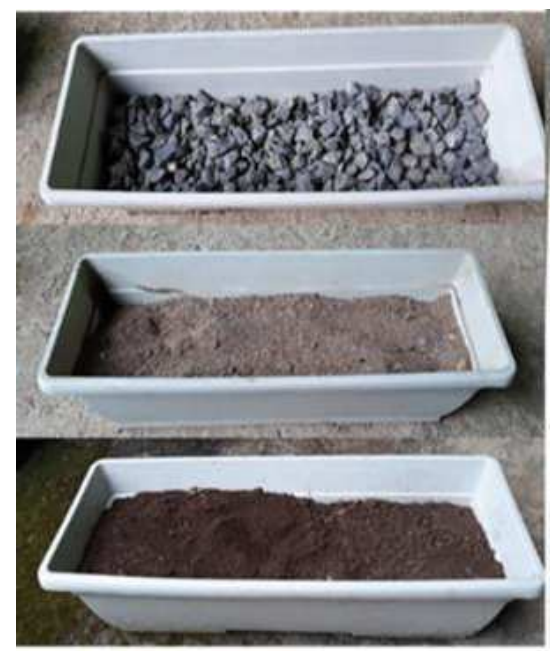

Fonte: Próprio autor (2020).

O passo seguinte é a colocação da terra preta, onde serão inseridos os vegetais. Por fim, coloca-se a terra vegetal que servirá de cobertura do solo e proteção contra as intempéries (Figura 12).

Figura 12: Mudas plantadas sobre terra preta e demais camadas de substrato adequado ao cultivo.

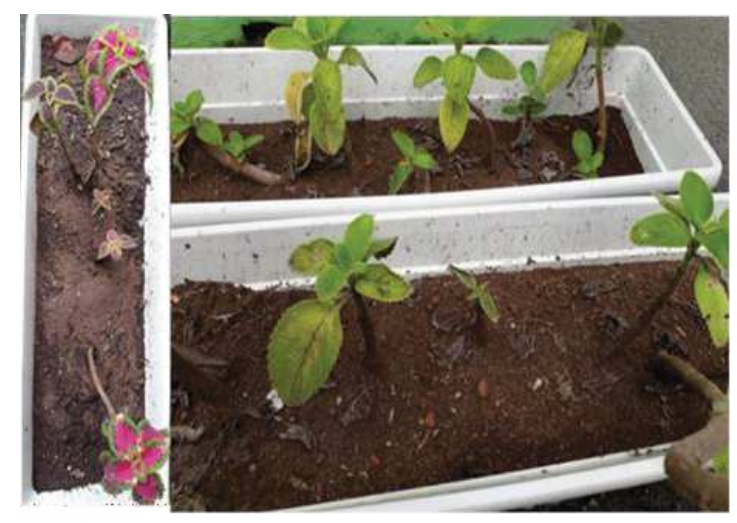

Fonte: Próprio autor (2020).

Ao longo deste processo os estudantes podem ser estimulados a pensarem mais sobre o assunto com perguntas como: Qual a relação das pedras com a drenagem da água? Por que a areia pode fornecer algum mineral à planta? Qual o motivo do solo precisar de proteção contra as intemperes? 


\section{$4^{\text {a }}$ Etapa - Confecção de lâminas para o estudo da Anatomia Vegetal.}

\section{Tempo de aplicação: $\underline{4 \text { aulas }}$}

\section{Materiais necessários:}

- Isopor

- Gilete de barbear

- Placa de Petri ou outro recipiente com água

- Pincel

- Amostral de vegetais

- Microscópio

- Massa de modelar

A Anatomia Vegetal é responsável pelo estudo dos tecidos vegetais, incluindo a organização, características e estruturas de tecidos. O conteúdo destas aulas apresenta como tema o tecido meristemático, além dos tecidos adultos primário e secundário - revestimento: epiderme e periderme; preenchimento e sustentação: parênquima, colênquima e esclerênquima; vascular: floema e xilema primários e secundários (Raven et al. 2014).

Esta etapa tem o objetivo de fornecer conhecimento sobre os tecidos e permitir a visualização de características importantes para o entendimento da morfologia dos vegetais.

O material de estudo será coletado das jardineiras onde foram cultivados pelos alunos e em seguida serão levados para o laboratório de ciências. No laboratório ocorrerá uma breve apresentação sobre o tema para servir como ponto de partida do estudo.

O próximo passo será o corte longitudinal e transversal das folhas, caules e raízes. Para isso os estudantes devem utilizar o isopor para segurar uma das partes do vegetal e a gilete de barbear para cortar o vegetal da forma mais fina possível. Neste momento o aluno irá colocar o corte dentro de uma placa de Petri com água para que este se mantenha esticado e liso, em seguida utilizará um pincel para transpor o corte da água para uma lâmina de microscopia e então levará esta lâmina para ser visualizada ao microscópio. Após a visualização de cada tecido, o professor fará uma explicação do material visualizado.

Para finalizar a atividade os estudantes se utilizarão de cada momento de explicação e visualização ao microscópio para construir modelos dos tecidos estudados com massa de modelar. Esta atividade é de extrema importância para a fixação do conteúdo, tendo o 
objetivo de permitir a visualização de algo que pode parecer abstrato, devido à necessidade de utilização de microscópio para enxergar os tecidos.

\section{Avaliação da sequência didática}

A avaliação será em processo, ou seja, no decorrer de toda a sequência didática, mediante a participação e empenho dos estudantes nas atividades propostas. Questões sobre o tema serão colocadas na prova bimestral.

\section{Agradecimentos}

Ao Sr. Sérgio Monteiro, coordenador do projeto Arranjo Produtivo Local de Plantas Medicinais do Palácio Itaboraí - FIOCRUZ Petrópolis.

O presente trabalho foi realizado com o apoio da Coordenação de Aperfeiçoamento de Pessoal de Nível Superior - Brasil (CAPES) - Código de Financiamento 001.

\section{Referências bibliográficas}

CACHAPUZ, A.; PRAIA, J. JORGE, M.. Da educação em ciência às orientações para o ensino das ciências: um repensar epistemológico. Ciênc. educ. (Bauru), Bauru, v. 10, n. 3, p. 363-381, 2004.

COMposta SÃo PAUlo. Cartilha Para Plantio De Pequenos Jardins Urbanos. São Paulo, 2014.

COSTA, E.A.; OLIVEIRA, I.V.G.; SANTOS, A.C.G.; PINTO, A.V.F.; MATOS, E.C. A.; PRATA, A.P.N.; CUNHA, M.M.S. Percepção De Professores Sobre A Disciplina Botânica Geral No Ensino Superior Alagoano. Revista InsignareScientia - RIS, Alagoas, v. 2, n. 4, p. 278-296, 2019.

EMATER-PARÁ, GOVERNO DO PARÁ. Cartilha de Horta para Ambiente Residencial. Belém do Pará. 2020. 
LOPES, F.; BetTencourt, T. O Ensino Da Biologia Numa Perspectiva Por Pesquisa: Contributos De Uma Investigação Preliminar No Ensino Secundário. Enseñanza de lãs Ciencias, Barcelona,p. 508-511, 2009.

NEVES, A.; BÜNDCHEN, M. e LISBOA, C.P.. Cegueira Botânica: é possível superá-la a partir da educação? Ciência e Educação, Rio Grande do Sul, v. 25, n. 3, p. 745-762, 2019.

RAVEN, P.H.; EVERT, R.F; EICHHORN, S.E. Biologia Vegetal. $8^{\text {a }}$ ed. Ed. Guanabara Koogan S/A, RJ, 2014.

SASSERON, L. H.; CARVALHO, A. M. P. Alfabetização científica: uma revisão bibliográfica. Investigações em Ensino de Ciências. São Paulo, v. 16, n. 1, p. 59-77, 2011.

SENICIATO, T.; CAVASSAN, O.. Aulas De Campo Em Ambientes Naturais E Aprendizagem Em Ciências: Um Estudo Com Alunos Do Ensino Fundamental. Ciênc. educ. (Bauru), Bauru, v. 10, n. 1, p. 133-147, 2004.

SIlVA, J.J.L., CAVAlCANTE, F.L.P.; XAVIER, V.F.; GOUVEIA, L.F.P. Produção De Exsicatas Como Auxílio Para O Ensino De Botânica Na Escola. Conex. Ci. e Tecnol. Fortaleza/CE, v. 13, n. 1, p. $30-37,2019$.

TOWATA, N. et al. Análise Da Percepção Dos Licenciandos Sobre O "Ensino De Botânica Da Educação Básica”. Revista da SBenBio, São Paulo, v.3, p.1603-12, 2010.

WANDERseE, J. H.; SCHUSSler, E. E. Toward A Theory Of Plant blindness. Plant Science Bulletin, Ohio v.47, p.2-9, 2002. 


\section{UFJF - UNIVERSIDADE FEDERAL DE JUIZ DE FORA - $\mathrm{MG}$}

\section{PARECER CONSUBSTANCIADO DO CEP}

\section{DADOS DO PROJETO DE PESQUISA}

Título da Pesquisa: ENSINANDO BOTÂNICA NA ESCOLA

Pesquisador: ROBERTO CEZAR TAVELA

Área Temática:

Versão: 5

CAAE: 32700519.5 .0000 .5147

Instituição Proponente: Universidade Federal de Juiz de Fora UFJF

Patrocinador Principal: Financiamento Próprio

\section{DADOS DO PARECER}

Número do Parecer: 4.561 .645

\section{Apresentação do Projeto:}

As informações elencadas nos campos "Apresentação do Projeto", "Objetivo da Pesquisa" e "Avaliação dos Riscos e Benefícios" foram retiradas do arquivo Informações Básicas da Pesquisa.

"Esse trabalho tem como objetivo a produção de uma sequência didática que visa desenvolver o interesse e o conhecimento pelo estudo da botânica. O trabalho tem atividades como cultivo de duas espécies do gênero Plectranthus, confecção de lâminas histológicas e produção de modelos de tecidos vegetais com massa de modelar. Para a validação desta sequência didática será feito um questionário para professores de biologia por meio

da plataforma Google com o aplicativo Google formulários, que fornecerá dados estatísticos. A proposta inicial era aplicar essa sequência didática aos alunos de ensino médio. Em virtude da Pandemia COVID-19, a sequência didática não será aplicada aos alunos, e sim validada pelos professores de ensino médio da rede pública de ensino. O trabalho que será desenvolvido fará com que os professores validem uma sequência didática em que os alunos aprimorem seus conhecimentos sobre as plantas, e possam refletir sobre a importância dos vegetais e sua relação com a sociedade.".

\section{Objetivo da Pesquisa:}

"Objetivo Primário: O objetivo do presente estudo é produzir uma sequência didática que se fundamente no cultivo de plantas medicinais e a utilização de seus órgãos vegetais para desenvolver o interesse e o conhecimento pelo estudo da botânica. A validação da sequencia

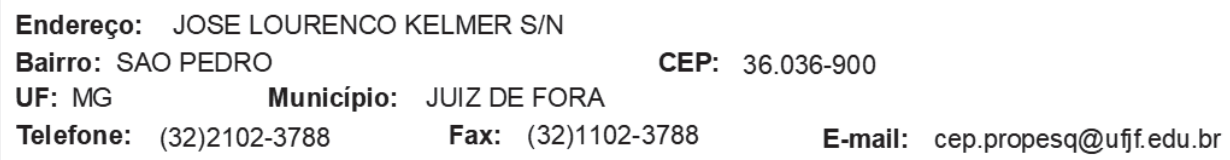




\section{은 SERES HUMANOS Uff FEDERAL DE JUIZ DE FORA - $\mathrm{MG}$}

didática será realizada pelos professores de ensino médio.".

"Objetivo Secundário: -Engendrar uma sequência didática que permita a qualquer professor reproduzir as atividades em outras escolas e instituições de ensino e moldá-la de acordo com sua realidade. -Validar essa sequência didática através de formulários a serem preenchidos pelos professores de maneira remota".

\section{Avaliação dos Riscos e Benefícios:}

"Os riscos aos participantes são mínimos. Existe o risco de perda de confidencialidade, porém, para minimizá-lo, quando necessário, os participantes serão identificados por pseudônimos ou códigos, a fim de preservar suas identidades; além disso, os dados serão manipulados apenas pelos pesquisadores. Caso algum participante se sinta constrangido ou incomodado em responder a alguma questão, é garantido o direito de cessar sua

participação na pesquisa. Aprimorar os conhecimentos sobre botânica, aprendendo sua importância para a natureza e para a sociedade.".

\section{Comentários e Considerações sobre a Pesquisa:}

O projeto está bem estruturado, delineado e fundamentado, sustenta os objetivos do estudo em sua metodologia de forma clara e objetiva, e se apresenta em consonância com os princípios éticos norteadores da ética na pesquisa científica envolvendo seres humanos elencados na resolução 466/12 do CNS e com a Norma Operacional № 001/2013 CNS.

\section{Considerações sobre os Termos de apresentação obrigatória:}

O protocolo de pesquisa está em configuração adequada, apresenta FOLHA DE ROSTO devidamente preenchida,com o título em português, identifica o patrocinador pela pesquisa, estando de acordo com as atribuições definidas na Norma Operacional CNS 001 de 2013 item 3.3 letra a; e 3.4.1 item 16. Apresenta o TERMO DE CONSENTIMENTO LIVRE ESCLARECIDO em linguagem clara para compreensão dos participantes, apresenta justificativa e objetivo, campo para identificação do participante, descreve de forma suficiente os procedimentos, informa que uma das vias do TCLE será entregue aos participantes, asseguraa liberdade do participante recusar ou retirar o consentimento sem penalidades, garante sigilo e anonimato, explicita riscos e desconfortos esperados, indenização diante de eventuais danos decorrentes da pesquisa, contato do pesquisador e do CEP e informa que os dados da pesquisa ficarão arquivados com o pesquisador pelo período de cinco anos, de acordo com as atribuições definidas na Resolução CNS 466 de 2012, itens:IV letra b; IV.3 letras a,b,d,e,f,g e h; IV. 5 letra d e XI.2 letra f. Apresenta o INSTRUMENTO DE COLETA DE DADOS de forma pertinente aos objetivos delineados e preserva os 


\section{UFJF - UNIVERSIDADE FEDERAL DE JUIZ DE FORA - MG}

participantes da pesquisa. O Pesquisador apresenta titulação e experiência compatível com o projeto de pesquisa, estando de acordo com as atribuições definidas no Manual Operacional para CPEs. Apresenta DECLARAÇÃO de infraestrutura e de concordância com a realização da pesquisa de acordo com as atribuições definidas na Norma Operacional CNS 001 de 2013 item 3.3 letra h.

\section{Conclusões ou Pendências e Lista de Inadequações:}

Diante do exposto, o projeto está aprovado, pois está de acordo com os princípios éticos norteadores da ética em pesquisa estabelecido na Res. 466/12 CNS e com a Norma Operacional No 001/2013 CNS. Data prevista para o término da pesquisa: julho de 2021.

\section{Considerações Finais a critério do CEP:}

Diante do exposto, o Comitê de Ética em Pesquisa CEP/UFJF, de acordo com as atribuições definidas na Res. CNS 466/12 e com a Norma Operacional No001/2013 CNS, manifesta-se pela APROVAÇÃO do protocolo de pesquisa proposto. Vale lembrar ao pesquisador responsável pelo projeto, o compromisso de envio ao CEP de relatórios parciais e/ou total de sua pesquisa informando o andamento da mesma, comunicando também eventos adversos e eventuais modificações no protocolo.

Este parecer foi elaborado baseado nos documentos abaixo relacionados:

\begin{tabular}{|c|c|c|c|c|}
\hline Tipo Documento & Arquivo & Postagem & Autor & Situação \\
\hline $\begin{array}{l}\text { Informações Básicas } \\
\text { do Projeto }\end{array}$ & $\begin{array}{l}\text { PB_INFORMAÇOES_BASICAS_DO_P } \\
\text { ROJETO 1317662.pdf }\end{array}$ & $\begin{array}{c}24 / 02 / 2021 \\
21: 03: 52\end{array}$ & & Aceito \\
\hline $\begin{array}{l}\text { Projeto Detalhado / } \\
\text { Brochura } \\
\text { Investigador }\end{array}$ & Projetodetalhado.pdf & $\begin{array}{c}24 / 02 / 2021 \\
20: 20: 49\end{array}$ & $\begin{array}{l}\text { ROBERTO CEZAR } \\
\text { TAVELA }\end{array}$ & Aceito \\
\hline $\begin{array}{l}\text { TCLE / Termos de } \\
\text { Assentimento / } \\
\text { Justificativa de } \\
\text { Ausência }\end{array}$ & TCLE_.docx & $\begin{array}{c}07 / 02 / 2021 \\
23: 12: 45\end{array}$ & $\begin{array}{l}\text { ROBERTO CEZAR } \\
\text { TAVELA }\end{array}$ & Aceito \\
\hline Outros & QUESTIONARIOROFESSORES.docX & $\begin{array}{c}19 / 12 / 2020 \\
22: 55: 56\end{array}$ & $\begin{array}{l}\text { ROBERTO CEZAR } \\
\text { TAVELA }\end{array}$ & Aceito \\
\hline Outros & PRODUTOTCMROBERTO.docx & $\begin{array}{c}25 / 10 / 2020 \\
15: 35: 52\end{array}$ & $\begin{array}{l}\text { ROBERTO CEZAR } \\
\text { TAVELA }\end{array}$ & Aceito \\
\hline Outros & TermodeSigilo.docx & $\begin{array}{c}27 / 03 / 2020 \\
20: 17: 13\end{array}$ & $\begin{array}{l}\text { ROBERTO CEZAR } \\
\text { TAVELA }\end{array}$ & Aceito \\
\hline Folha de Rosto & FolhadeRostoc.pdf & $\begin{array}{l}27 / 03 / 2020 \\
20: 12: 49\end{array}$ & $\begin{array}{l}\text { ROBERTO CEZAR } \\
\text { TAVELA }\end{array}$ & Aceito \\
\hline $\begin{array}{l}\text { Declaração de } \\
\text { Instituição e } \\
\text { Infraestrutura }\end{array}$ & Infraestrutura.pdf & $\begin{array}{c}24 / 03 / 2020 \\
14: 40: 28\end{array}$ & $\begin{array}{l}\text { ROBERTO CEZAR } \\
\text { TAVELA }\end{array}$ & Aceito \\
\hline
\end{tabular}


UFJF - UNIVERSIDADE SERES HUUMNON UfJ FEDERAL DE JUIZ DE FORA MG

Situação do Parecer:

Aprovado

Necessita Apreciação da CONEP:

Não

JUIZ DE FORA, 26 de Fevereiro de

2021

Assinado por:

Jubel Barreto

(Coordenador

(a))

Endereço: JOSE LOURENCO KELMER S/N

Bairro: SAO PEDRO

CEP: $\quad 36.036-900$

UF: MG Municipio: JUIZ DE FORA

Telefone: (32)2102-3788 Fax: (32)1102-3788

E-mail: cep.propesq@uff.edu.br 